\title{
واقع حوكمة كلية التربية \\ بجامعة القصيم في ضوء رؤية المملكة 2030
}

\author{
رغد صالح محمد الروضان
}

كلية التربية- جامعة القصيم- المملكة العربية السعودية

raghad488@hotmail.com 


\title{
و اقع حوكمة كلية التربية بجامعة القصييم في ضوء رؤية المملكة 2030
}

\author{
رغد صالح محمد الروضيان \\ كلية التربية- جامعة القصيم- المملكة العربية السعودية معلدان \\ raghad488@hotmail.com
}

DOI: https://doi.org/10.31559/EPS2021.9.2.18 2020/4/18 2020/5/16 2020/4/29 مبتول البحثة البحث البحث: 2018

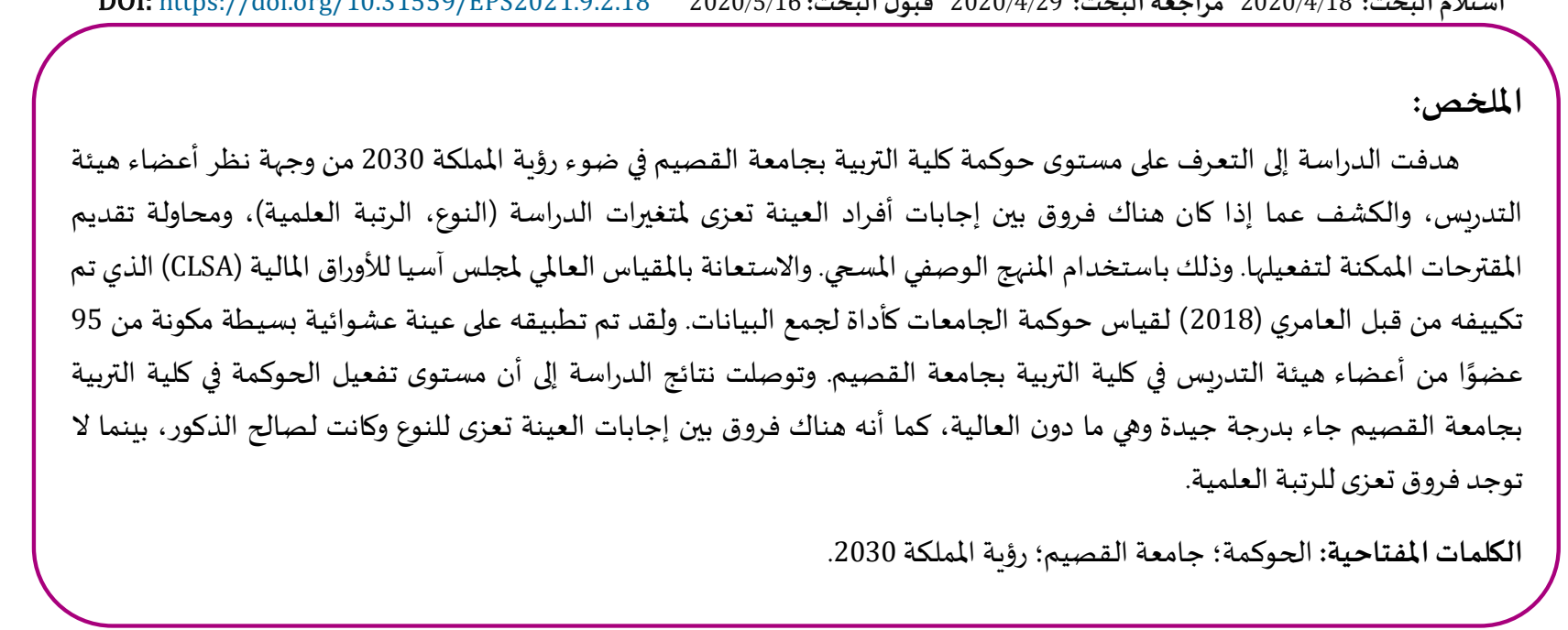

المقدمة:

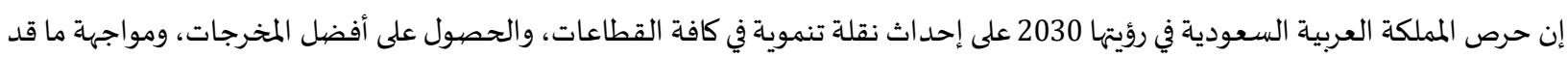

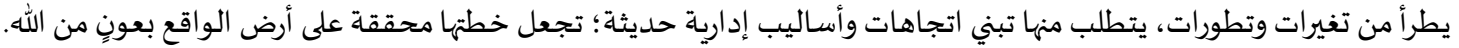

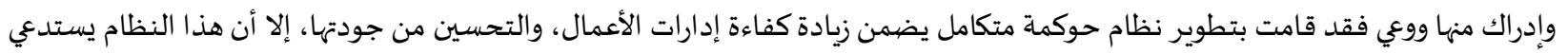
المشاركة الجادة والفاعلة في تطبيقه من قبل كافة مؤسسات الدولة سواء على المستوى السياسي، الاقتصادي، الاجتماعي، التربوي (الشمري، 2018،

ومن زاوية أخرى فإن ضعف تطبيق الحوكمة في تلك المؤسسات سيحول إلى خلل في إداراتها، والذي قد يتشكل في عدة صور منها: عدم استقرار

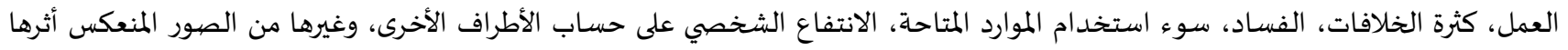

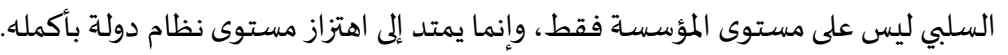

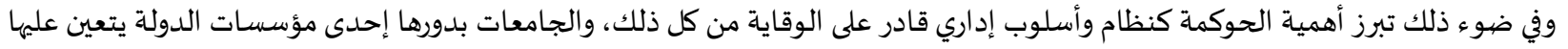

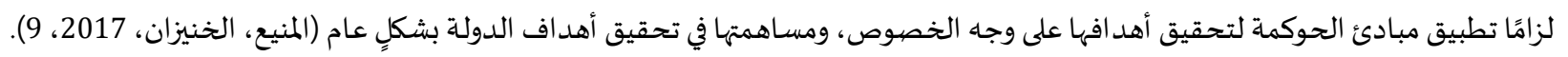

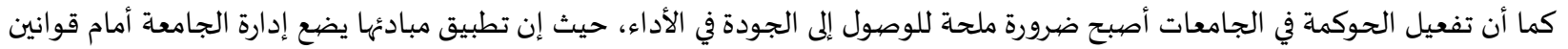

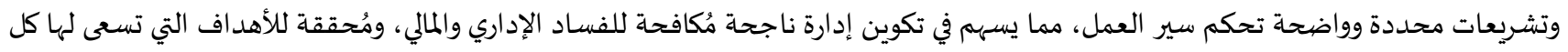

ويلحظ في الآونة الأخيرة كثرة المطالبات على تطبيق الحوكمة في الجامعات؛ والسبب يعود في ذلك إلى ما تعانيه كثير من الإدارات الجامعية من

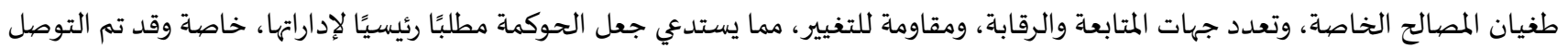

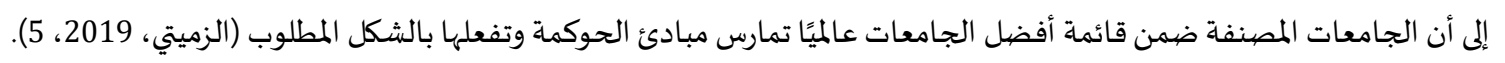


لذا فإن الجامعات في الدول النامية لا تزال متوانية في تطبيقها للحوكمة، على الرغم من ثبوت ارتباطها في القدرة على الارتقاء بالتعليم العالي

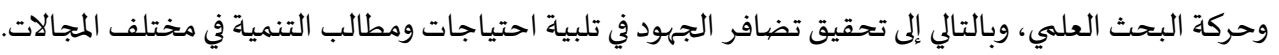

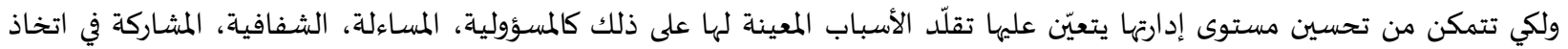
القرارات، وهي بذلك تمثل المبادئ الرئيسية للحوكمة المساهمة في تحقيق الأثر الإيجابي الكبير على إدائها، والارتقاء بجدودة مخرجاتها (محمد، وعبداء الرازق، 2019، 347).

مشكلة الدراسـة:

تماشيًا مع رؤية المملكة العبية السعودية 2030، وسعيًا للمساهمة في تحقيق إحدى برامجها المتمثلة في تعزيز حوكمة العمل الحكومي، كان

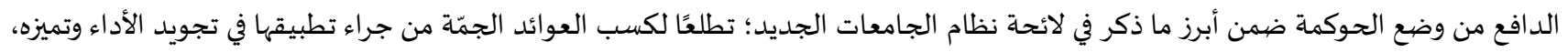

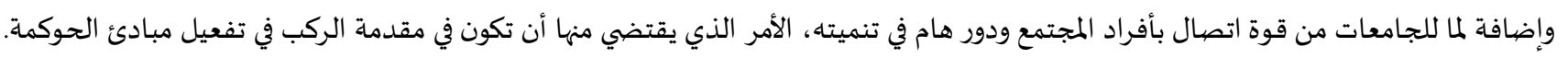

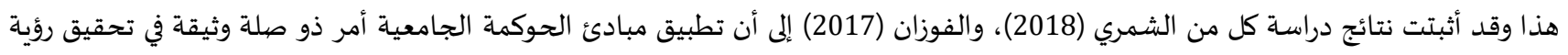

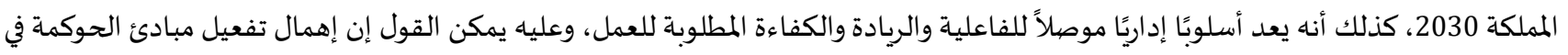
الجامعات السعودية سيؤدي إلى ضعف مستوى إداراتها. ولقد تفاوتت الدراسات حول تحديد مستوى الحوكمة في الجامعات السعودية حيث أشارت دراسة المنيع المدات والخنيزان (2017) إلى أن واقع تطبيق

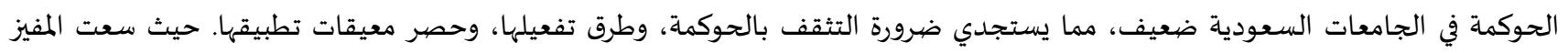

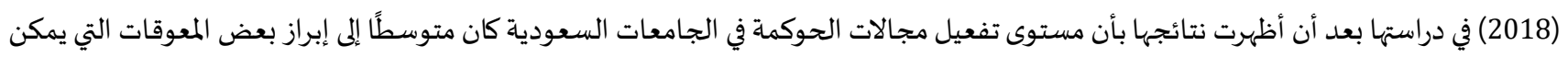

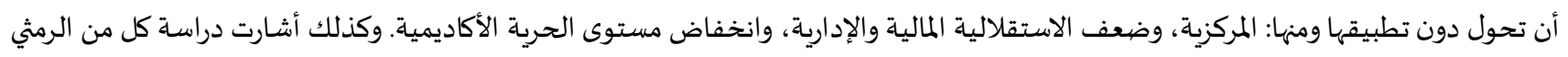

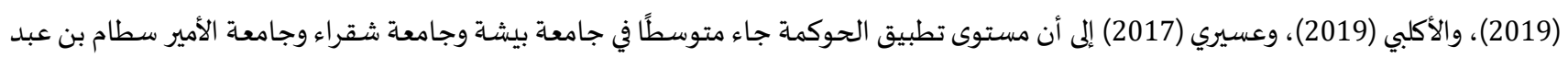

ولعل مما يحث ويشجع لزيادة الاهتمام بتفعيل الحوكمة في الجامعات ما أسفرت عنه نتائج العديد من الدراسات عن الأثر الإيجابي للحوكمة

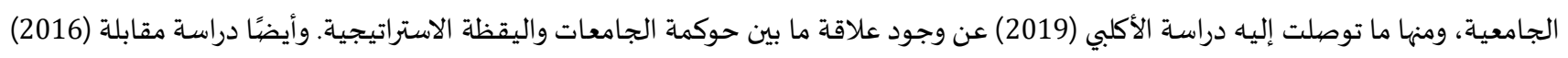

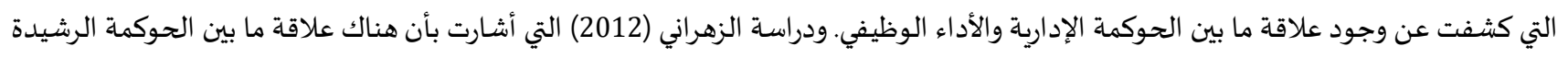
في الجامعات الأهلية السعودية والرضا الوظيفي والولاء التنظيمي لدى أعضاء العضاء هيئة التدريس.

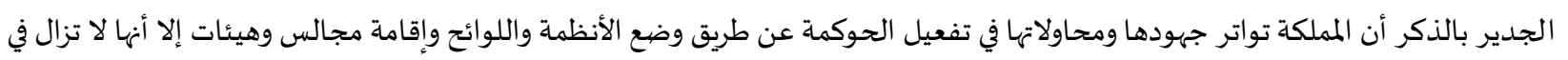

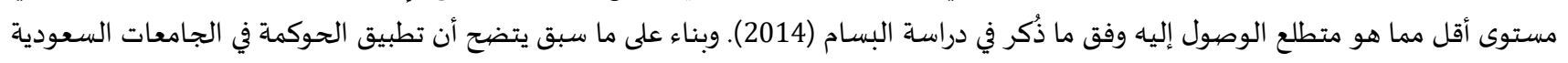

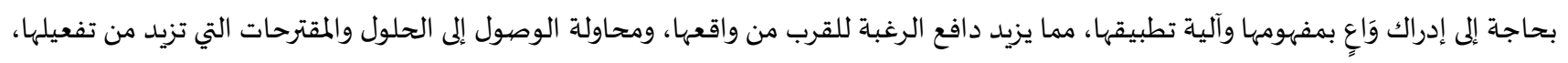

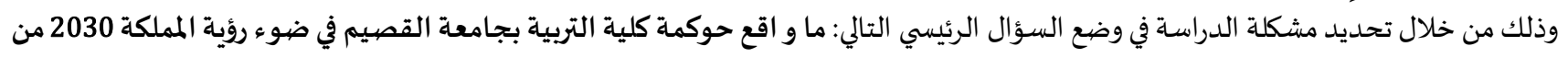

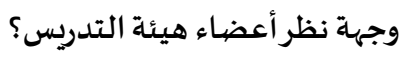

وستتم الإجابة عليه من خلال الإجابة عن الأسئلة الفرعية التالية:

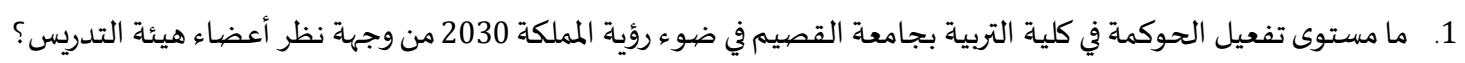
2. هل توجد فروق ذات دلالة إحصائية بين متوسط إجابات أعضياء هيئة التدريس التي تعزى لمتغيرات الدراسة: (الجنس، الرتبة العلمية) ؟

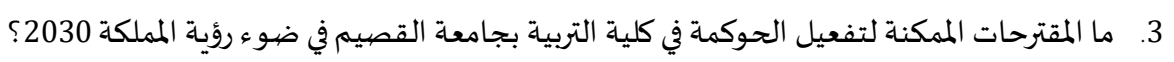

أهداف الدراسة:

1. التعرف على مستوى تفعيل الحوكمة في كلية التربية بجامعة القصيم في ضوء رؤية المملكة 2030 من وجهة نظر أعضاء هيئة التدريس. 2. الكشف عما إذا كان هناك فروق ذات دلالة إحصائية بين متوسط إجابات أعضياء هيئة التدريس التي تعزى لمتغيرات الدراسة: (الجنس،

الرتبة العلمياة).

3. تقديم المقترحات الممكنة لتفعيل الحوكمة في كلية التربية بجامعة القصييم في ضوء رؤية المملكة 2030. 


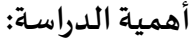

يمكن إبراز أهمية الدراسـة النظرية والتطبيقية على النحو التالي:

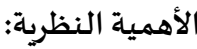

اتفاقها مع سعي المملكة في تحقيق رؤية 2030، وذلك من خلال تعزيز برنامج حوكمة العمل الحكومي، ومحاولة زيادة الوعي بمفهومه وتطبيقه.

تناولها مفهومًا إداريًا حديثًا تندر البحوث العلمية المعمولة حوله، والغالب منها تم تطبيقه على البنوك والمصارف والمؤسسات الخاصية. مساهمتها في إثراء المكتبات وقواعد المعلومات العربية بالمادة العلمية لموضوع الحوكماة.

الأهمية التطبيقية:

يتطلب تفعيل الحوكمة المزيد من الإسهامات البحثية التي تعتبر مثابة الدليل المرشـد في عملية التنفيذ.

تمكن واضعي القرارات والسياسات من إصدار لوائح جديدة أكثر ملائمة لحوكمة العمل في الجامعات.

تمد المسؤولين بجوانب القوة والضعف في تطبيق الحوكمة، مما يساعدهم على تعزيز الصالح، ومعالجة القصور.

حدود الدراسـة:

الحدود الموضوعية: التعرف على واقع الحوكمة في كلية التربية بجامعة القصيم في ضوء رؤية المملكة 2030 من خلال التركيز على ثلاثة مبادئ: (المساءلة، الشفافية، المسؤولية)؛ وذلك لصدورها بالنص الصريح ضمن رؤية المملكة العربية السعودية 2030. الحدود المكانية: كلية التربية بجامعة القصيم؛ ولقد تم تحديد ذلك وفق الإمكانات الزمنية المتاحة لإنجاز البحث الحدود البشرية: أعضياء هيئة التدريس في كلية التربية بجامعة القصيم؛ إيمانًا بوعيهم لأنظمة الجامعة والقوانين السائدة وقربهم من واقعها، وإدراكهم مدى أهمية تقديم إجابات صادقة وموضيوعية. الحدود الزمانية: الفصل الدراسي الثاني من عام 1441هـين.

مصطلحات الدراسـة: الحوكمة (Governance): يعرفها أبو النصر (2015، 45) بأنها: "الإدارة الرشيدة القائمة على النزاهة والشفافية والمساءلة والمحاسبية ومكافحة

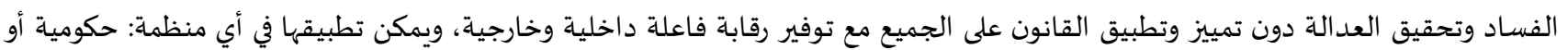
أهلية، وعلى أي مستوى: دولي أو إقليمي أو محلي، وفي أي مجال: مجال السلع أو مجال الخدماتئ.

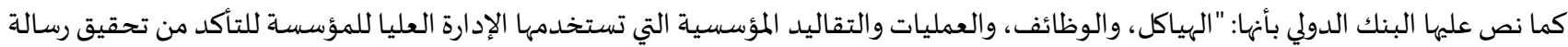
المؤسسة"(تعالبي، 2015، 21). حوكمة الجامعات (University governance): يقصد بها: "قدرة الجامعات على تحقيق أهدافها بمستوى عال من الجودة، وتحسين أدائها باتباع خطط فاعلة وأساليب مناسبة من خلال الإدارة الرشيدة"(العريني، 2014، 117).

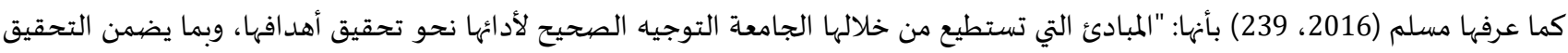
المتوازن لمتطلبات جميع الأطراف". جامعة القصيم (Qassim University): هي جامعة من الجامعات الحكومية الشاملة في المملكة العربية السعودية إذ تشتمل على 71 تخصصيًا علميًا

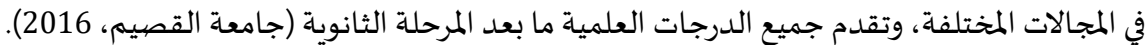

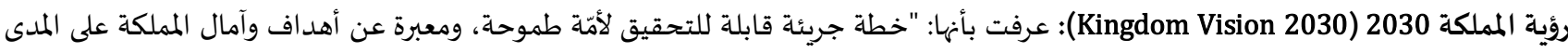

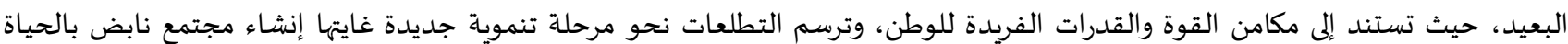

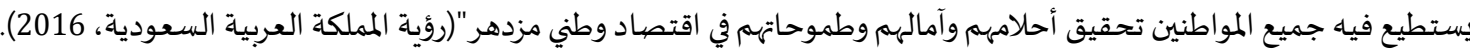

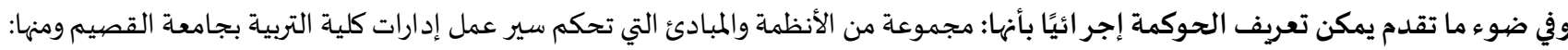
(المساءلة، الشفافية، المسؤولية)، وذلك بهدف: تحقيق المصلحة لكافة الأطراف، وتجويد الأداء والارتقاء بهاه، والمساهمة الجزئية في تطبيق خطة المملكة

التنموية.

الإطار النظري:

أولاً: الحوكمة:

لقد تزايد الحرص على ما يُعرف بالحوكمة مع أحداث الهزّة الاقتصادية الحاصلة في أواخر القرن العشرين، حيث تدهورت أوضاع كثير من

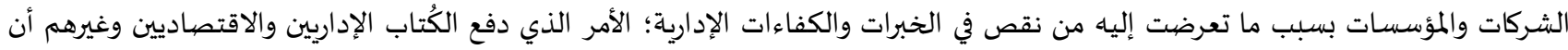


يتوجهوا إلى الحديث عن ثقافة الحوكمة وما لها من عوائد في تجويد العمل وإصلاحه، إضافة لإمكانية تفعيلها على كافة القطاعات والمؤسسات (أبو النصرر، 2015، 15) 1. الحوكمة في اللغة والاصطلاح: الحكم في اللغة هو صفة من صفات الله وهو أحكم الحاكمين، حيث تم تداوله في بادئ الأمر بعد التعريب بلفظة الحاكمية مما جلب الاعتراض

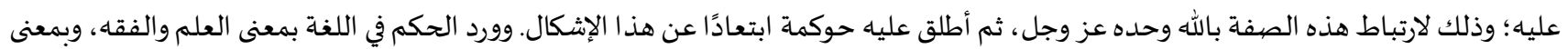

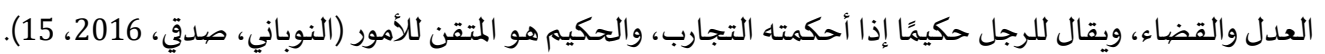

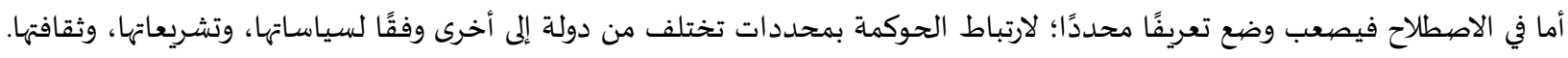
ولكن يمكن ذكر عددًا منها: إذ تعني الحوكمة: "وجود نظم تحكم العلاقات بين الأطراف الأساسية التي تؤثر في الأداء، كما تشمل مقومات أشمات تقوية المؤسسات على المدى البعيد،

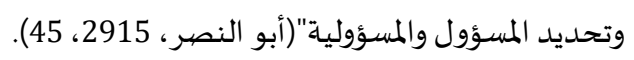

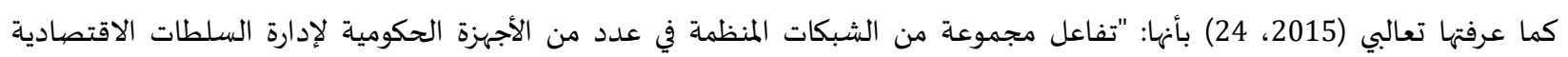

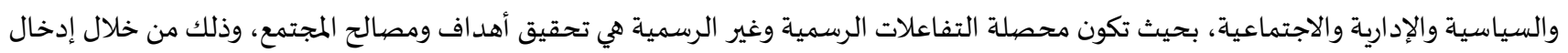

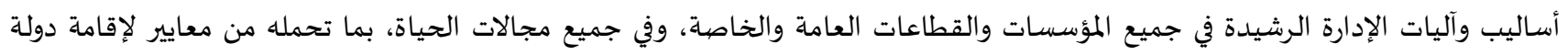

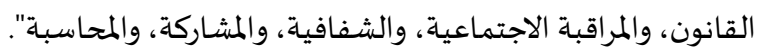

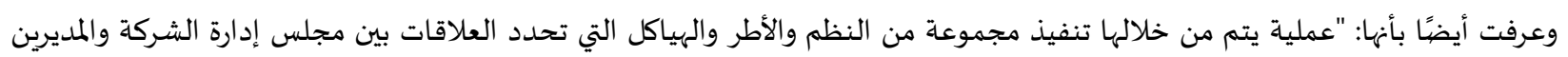

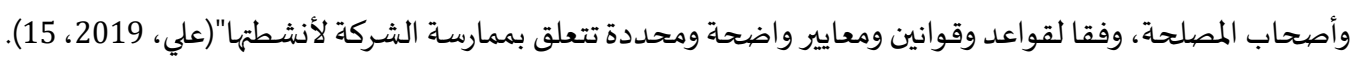

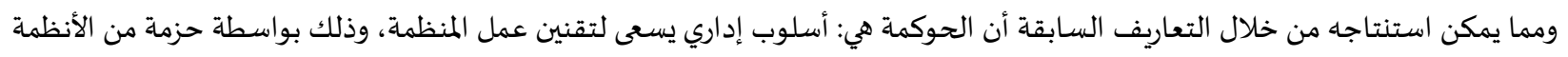

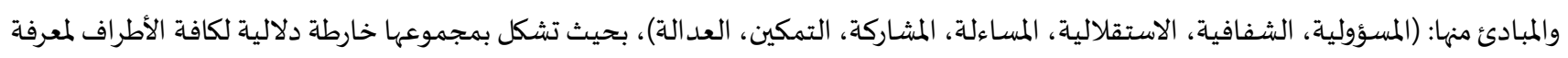

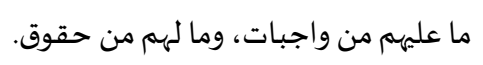

2. 2 أهمية الحوكمة:

تتجلى أهمية تطبيق الحوكمة إجمالاً في قدرتها على الارتقاء بجودة العمل، ويمكن تفصيلها بمجموعة من النقاط كما حددتها منظمة اليونيسكو

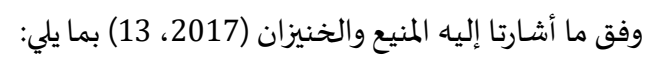
توصل إلى درجة عالية من النزاهة. تمكن من التعامل بعد الة وحيادياة مع جميع الأفراد. تمنع ممارسات الفساد والانحرافات الداخلية. تحقق الكفاءة في الأداء، وبالتالي المساهمة في سير حركة التنمية. ترفع مستوى الثقة بالمؤسسات. تقلل الوقوع بالخطأ، أو التقصير في أداء العمل. تروسل. تسهم في توفير فرص للعمل.

تكشف عن التغيرات التي تطرأ على العمل والعمال. كما يبرز الشريف وآخرون (2013، 170) أهمية الحوكمة في النقاط التالية: تساعد على التكافؤ والربط ما بين عمليات الإنفاق والإنتاج. تشجع على التنافسية في الإداء سواء على الصعيد الد اخلي للمنظمة أو الخارجي. تحفظ حقوق ومسؤوليات كافة الأفراد العاملين. تحسن من عملية صنع القرارات ذات العلاقة بالمنظمة.

تسعى لإحداث توازن ما بين الغايات الاقتصيادية والحاجات المجتمعية.

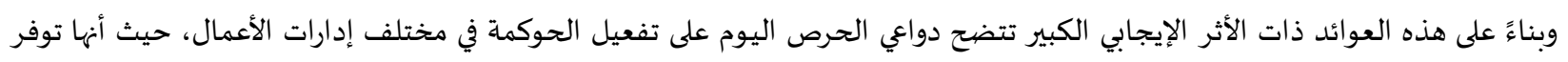
أسلوبًا ناجحًا يقود إلى استمرارية العمل بشكل أكثر كفاءة وفاعلية، وبطريقة تؤدي إلى محاربة كل ما قد يؤدي إلى كساده وفسادها. 
3. n محددات الحوكمة:

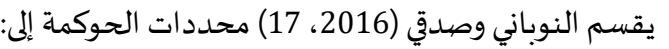
• محددات داخلية: وهي التي تعبر عن القواعد والأسس (الداخلية) أي: الخاصية بمنظمة ما، بحيث تحدد منهجيتها في اتخاذ القرارات، وتوزيع السلطات، واجراء الرقابات الداخلية، مع ضرورة المراعاة والأخذ بالحسبان ألا تتعارض مع مصالح جميع الأطراف، وأن يتم التعامل معهم بحيادية. هحدددات خارجية: وهي المحددات التي تمثل البيئة التي توجد بها المنظمة، والتي من الطبيعي أن تختلف من مكان لآخر، أو من دولة لأخرى. ثانيًا: حوكمة الجامعات: ارتبطت الحوكمة في البدايات بقطاع الأعمال، إلا أهها لم تقتصبر على ذلك المجال فحسب، فبعدما أثبتت فاعليتها في ضبط العملية الإدارية لزم تطبيقها على كافة القطاعات والمؤسسـات، وأصبح تطبيقها يوضع كجزء هام في خطط التنمية، ومما يؤكد ذلك وضعها كأحد البرامج المحققة لرؤية

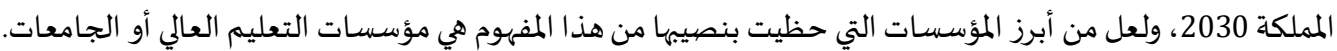

1

يقصد بها: "تطبيق مصفوفة النظم والمعايير التي تحكم أداء الجامعات بما يحقق أهداف الجامعة في ظل الشفافية، والمساءلة، والمشاركة من قبل

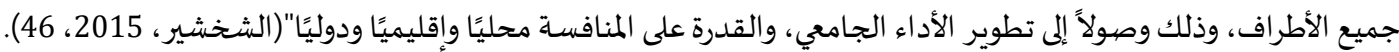
ويعرفها الشمري (2018، 375) بأها: "نهج إداري يقوم على الأخذ بمعايير الشفافية والمساءلة والاستقلالية ومشاركة جميع ذوي العلاقة في إدارة

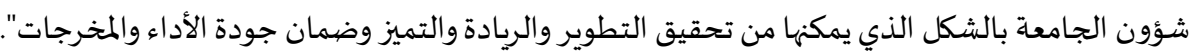
كما عرفت بأنها: "مجموعة النظم والقوانين والقرارات التي تهدف إلى تحقيق التميز والجودة في الأداء الإداري والتعليمي من خلال اختيار الأساليب

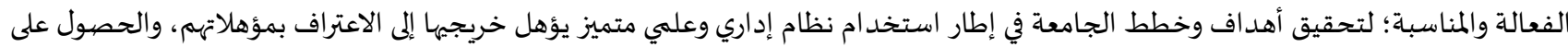
فرص عمل مناسبة لتخصصاتهم، ومواكبة التطور العلمي الحادث في العالم، مع تطوير أداء هذه المؤسسات إلى معايير التميز والجودة والتنمية المستدامة"(الزميتي، 2019، 9. 9.

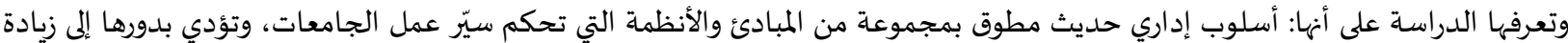
مستوى كفاءة وتميز الجامعات، وبشكل محقق لأهدافها دون أن يتعارض مع مصالح الأطراف المنتمين إلها. 2. أهداف حوكمة الجامعات:

تعتبر الحوكمة الجامعية حركة إصلاحية لمؤسسات التعليم العالي، وذلك لما تصبو إليه من أهداف تحددها مقيدش (2018، 490) بما يأتي: زيادة الخبرة الإدارية لدى المسؤولين في اللجان والمجالس الإدارية؛؛ لضمان مقدرتهم على المشاركة في صنع واتخاذ القرارات، ومواجهة ما قد يعترض

$$
\text { العمل من انحرافات والوقاية منها. }
$$

$$
\text { منح المجالس الإدارية القدرة على توفير أفضل الإمكانات لعمليتي التعليم والبحث. }
$$$$
\text { رفع مستوى التنافسية بين الجامعات في جودة مخرجاتها. }
$$$$
\text { تحسين الوضع التعليمي والإداري في الجامعات والارتقاء باه. }
$$

تحقيق الاستثمار الأمثل لموارد وإمكانات الجامعة.

تنمي القدرة على العمل ضمن فريق، وتزيد التفاعل بين كافة الأطراف.

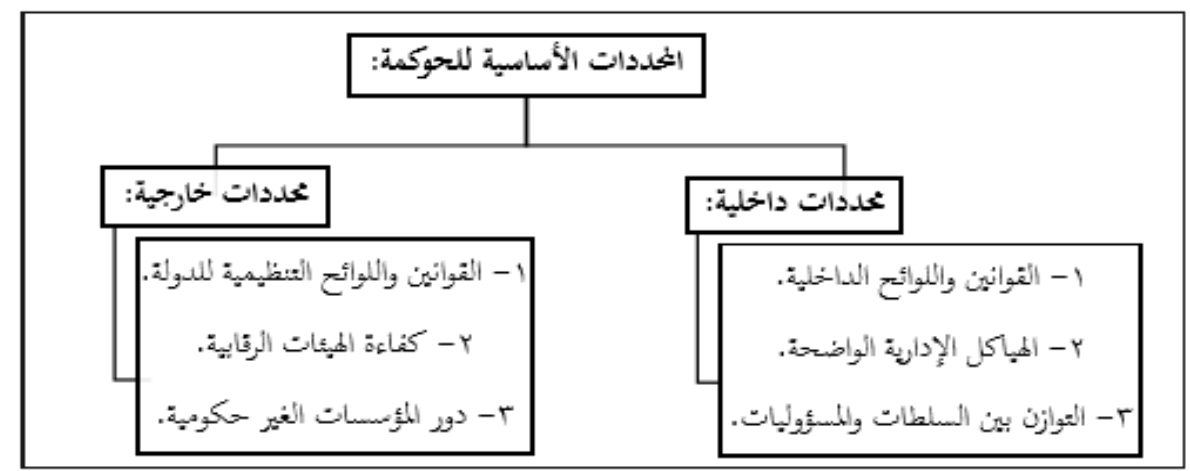

شكل (1): محددات الحوكمة

أبوحمام (2009، 28) 
3.

ترجع مقيدش (2010، 70) أسباب ظهور الحوكمة في الجامعات إلى:

الثورة المعلوماتية والتكنولوجية وما لحقها من تطورات وتغيرات.

محاولة لتحديث الأساليب الإدارية التقليدية، كما أن الحوكمة أصبحت من معالم الجامعات على المستوى العالمي. تزايد الاهتمام بعمليات صنع القرارات سواء على المستوى الإداري أو الأكاديمي.

تعدد المصدرين للخدمات التعليمية، وزيادة الحركة الأكاديمية للطلاب وأعضاء هيئة التدريس.

ضعحف مساهمة الجامعة في دفع عجلة التنمية؛ لتقصيرها في النواحي الأكاديمية من إنتاج للعلم والمعرفة. الاستعد اد لتوجهين يتوقع حدوثهما: عولمة التعليم وعولمة البحث العلمي، وذلك بجعلها أمرًا مشتركًا بين الدول.

انتشار الفساد في الجامعة الذي تتعدد صوره، ومنها: استخدام السلطة والمنصب للمصالح الخاصة الشخصية. الافتقار للكثير من القيم الأخلاقية سواء على مستوى العلاقات الشخصية التي يجب أن تبنى على الود والاحترام، أو على المستوى الأكاديمي التي

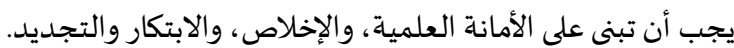
ضعف الثقة المتبادلة ما بين الجامعة والمجتمع. 4.

يذكر عبد الحكيم (2011، 319) مجموعاة من العناصر للحوكمة الجامعية المتمثلة بالتالي: وضيع نظام يتضمن سياسات وقوانين محددة، وواضحة، ومتاحة لاطلاع مجالس ولجان الجامعات، والكليات، والأقسام. تحديد الهياكل التنظيمية التي توضح بالتحديد السلطات والمسؤوليات التابعة لكل مجلس إداري، وتوثيق ذلك كتابيًا. تحديد الكيفية التي يتم من خلالها إشراك الطلاب بالقرارات المتعلقة بهم. امتلاك أصحاب المجالس واللجان للخبرة والمعرفة في هذا المجال. اتصاف المجالس واللجان بمعايير الجودة والاعتماد. التمكن من العمل الجماعي دون ترأس. القيام بتأهيل الأعضياء الجددد، والقيام بتحديث المعلومات في حال حدوث دورث أي تغيرات. توافر معايير محددة لتقيم المجالس واللجان. 5.

تناولت الأدبيات عدد من مبادئ الحوكمة الجامعية، ومنها ما أشارت إليه مقيدش (2018، 490): مبدأ الشفافية: ويقصد بهذا المبدأ الوضوح والكشف عن الأنظمة والسياسات التي تكفل حقوق جميع الأطراف (إداريين، أكاديميين، طلبة، عاملين)، وذلك بتحديد مالهم من حقوق وما عليهم من واجبات. مبدأ المشاركة: أي إتاحة الفرصة لأعضاء هيئة التدريس، والهيئة الإدارية، وكذلك الطلبة من المشاركة في تقديم اقتراحاتهم حول بعض الأنظمة والسياسات الخاصية بالجامعة. مبدأ المساءلة: وهو مبدأ يتعلق بأصحاب السلطة والمسؤولية فهم مسؤولين عن الأطراف الداخلية والخارجية، بحيث يكون هناك استحقاق لمحاسبتهم ولومهه كإجراء وعملية تقويمية. مبدأ الاستقلالية: ويعني توفير قدر من الحرية للجامعة في اتخاذ القرارات، وكذلك توفير الحرية لأعضاء هيئة التدريس والطلبة من الوصهول للمعرفة والحقيقة دون قيود أو مواجهة صعوبات. وتضيف العريني (2014، 121) ما يلي: مبدأ المساواة: بحيث يتم التعامل مع الجميع بحيادية، وعدالة، ودون تحيز. • مبدأ المسؤولية: ويتضمن هذا المبدأ تحديد المهام والمسؤوليات بكل دقة ووضوح، وبشكل يقود إلى تأديتها بشكل سليم ومتقن.

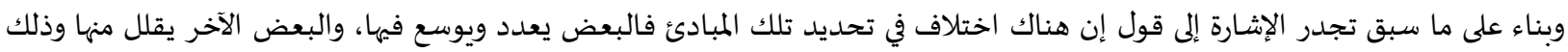
بتضمين أحدها بالأخرى، ولكن الأهم ألا يتم إهمال تطبيق مبدأ على حساب الآخر، فمبادئ الحوكمة تشكل سلسلة مترابطة ومكملة لبعضها؛ لتؤدي بكليتها حوكمة جيدة وفعالة. 
6. مراحل تطبيق حوكمة الجامعات:

أشارا الحدابي والعزيزي (2019، 41) إلى أن الحوكمة تحتاج إلى مراحل متسلسلة كالتالي:

مرحلة التمهيد: وتتضمن التعريف بالحوكماة، والغاية منها، والإقناع بها.

مرحلة وضع الأساس: وذلك بالتخطيط والتوصيف لكيفية عملها.

مرحلة وضع الإطار الزمني: ويعني تحديد أوقات القيام بها.

مرحلة التنفيذ: وهي مرحلة الشروع بتطبيقها.

مرحلة المراقبة: وتشمل متابعة سيرها، وتطويرها. 7.

يحدد الحدابي والعزيزي (2019) مجموعة من المعوقات لتطبيق الحوكمة في المؤسسات التعليمية منها:

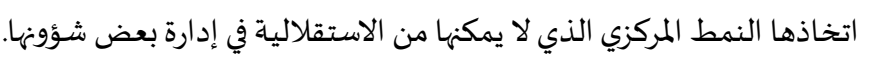

انتشار الثقافة الأبوية، والتي تعني أن رأي الكبير هو الذي يأخذ بالاعتبار حتى وإن كان على خطأ.

عدم تفعيل فكرة التقييم الصادر من الطلاب لأداء أعضياء هيئة التدريس.

تغيب بعض أعضاء هيئة التدريس عن أدوارهم، وغياب الجهاة الرقابية عنهم.

كما يشير مقيدش (2010، 73) إلى ما يلي:

غياب الشفافية، والمساءلة، والمشاركة في صنع القرارات، واتخاذ الصبغة البيروقراطية.

الافتقار للأنظمة والقوانين الموضوعة بشكل خاص لتتلاءم مع التعليم الجامعي.

القصور في الكيفية التي يتم بها اختيار الأسرة الجامعية من رؤساء، وعمداء، وأعضياء هيئة تدريس.

سيطرة وتأثير الجانب السياسي.

8. متطلبات ومقومات حوكمة الجامعات:

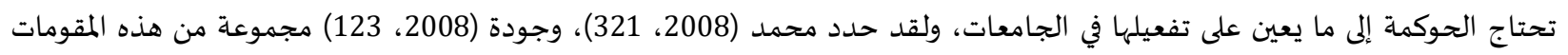

والمتطلبات كالتالي:

رسم خطة استراتيجياة، ونشرها ما بين أعضاء هيئة التدريس والإداريين.

متابعة سير تنفيذ الخطط الاستراتيجية.

وضع مقياس لتقييم أداء الإدارة التنفيذية.

توفير أنظمة رقابية.

توفر نظام اتصالات حديث.

الانضباط المالي.

توفير نظام حوافز.

الوضوح والشفافية في اتخاذ القرارات.

انتخاب أصحاب المصلحة لممثليهم.

الاقتناع والقبول بالأنظمة الإشرافية والرقابية.

توافر الثقة بين جمع الأطراف.

الوضوح في قواعد ومبادئ الحوكمة المتخذة.

تحديد آليات وامكانيات تطبيق الحوكمة.

تحديد الإجراءات المتضمنة التوجياء والإرشاد.

اختيار الأسرة الجامعية في ضوء الخبرة، والكفاءة، والدرجة العلمية، والولاء للوطن.

ثالثًا: رؤية المملكة 2030:

يصف محممد بن سلمان -حفظه الله- رؤية المملكة 2030 بأها: "رؤية الحاضر للمستقبل، التي نعمل بها اليوم لِلغد، بحيث تعبر عن طموحاتنا،

وتعكس قدرات بلادنا". 


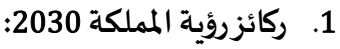
بنيت تلك الرؤية على ثلاث ركائز:

$$
\begin{aligned}
& \text { مجتمع حيوي. } \\
& \text { اقتصياد مزدهر. } \\
& \text { • وطن طموح. }
\end{aligned}
$$

2. الحوكمة في رؤية المملكة 2030:

كان للحوكمة حظ وافر من رؤية المملكة 2030، حيث اشتملت على العديد من مبادئها، فأشارت إلى اعتمادها على الشفافية والإفصاحساح في حال

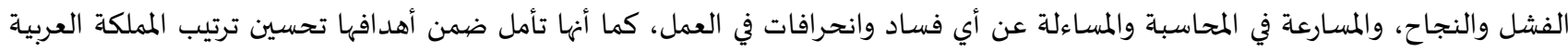

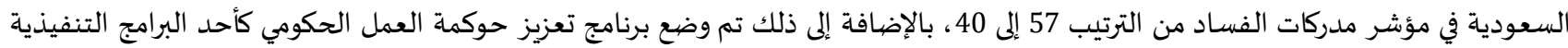

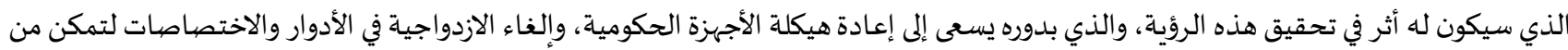

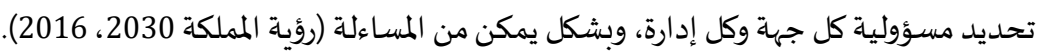

الدراسات السابقة: - n

سيتم عرض الدراسات السابقة العربية والأجنبية بحيث سوف تُدرج وفق ترتيبهما من الأحدث إلى الأقدم كما يلي: هدفت دراسة محسن وآخرون (Muhsin et al., 2020) إلى التعرف على العلاقة بين الحوكمة وجودة التدريس على رضا الطلاب، وكذلك دراسة

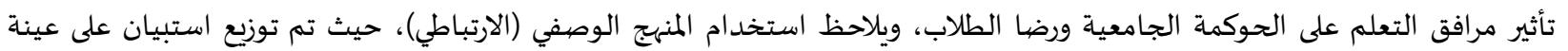

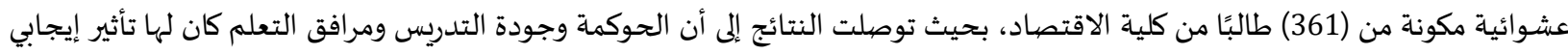

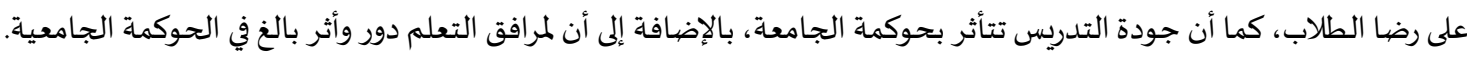
وكشفت دراسة الحدابي والعزيزي (2019) عن مستوى تفعيل مبادئ الحوكمة في الجامعات اليمنية، وذلك باستخدام المنهج الوصفي

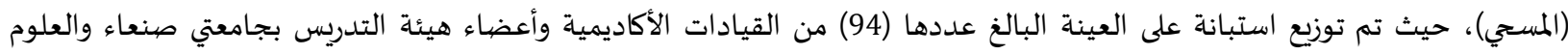

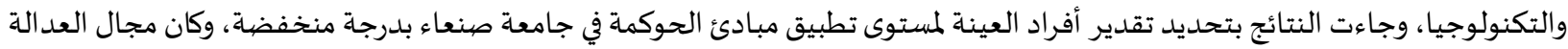

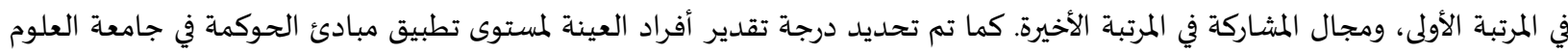

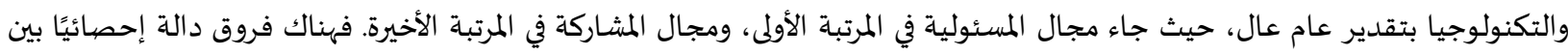

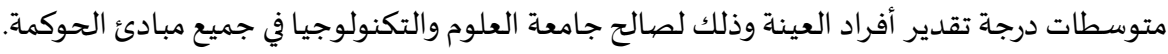

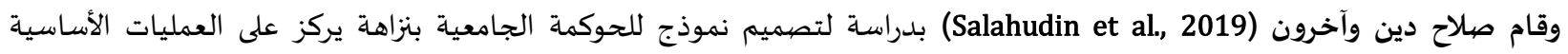

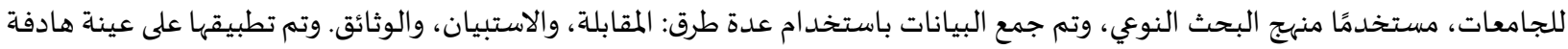

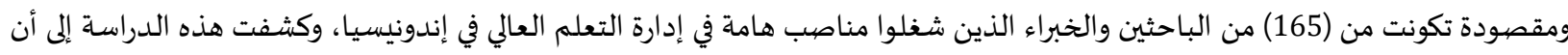

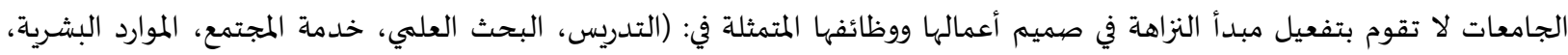
الميزانية، البنية التحتية، القيادة)، بالإضافة إلى انتشار ممارسات الفساد في الإدارات الجامعية.

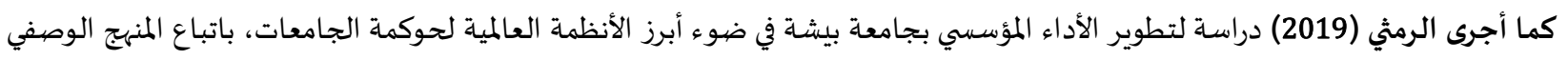

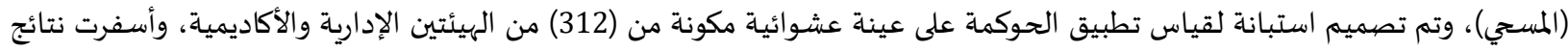

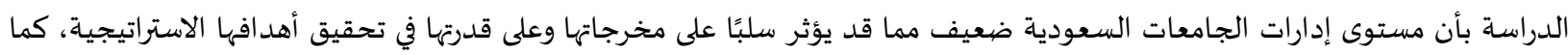

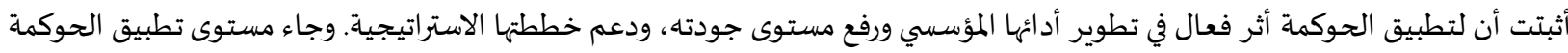
بجامعة بيشة بتقدير متوسط بشكل عام. وسعت دراسة سيدة وآخرين (Sayidah et al., 2019) إلى تحليل أهمية الجودة والحوكمة الجامعية في إندونيسيا، باستخدام منهج البحث

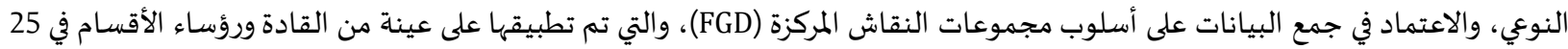

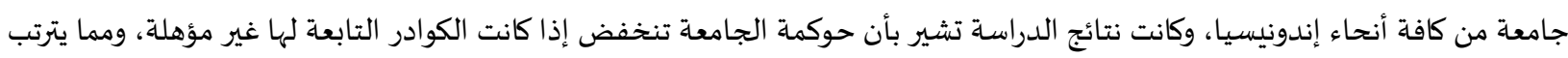

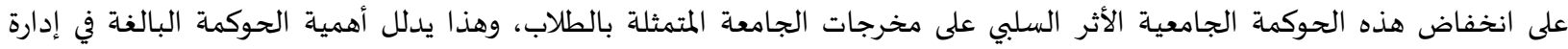
الجامعات ومخرجاتها.

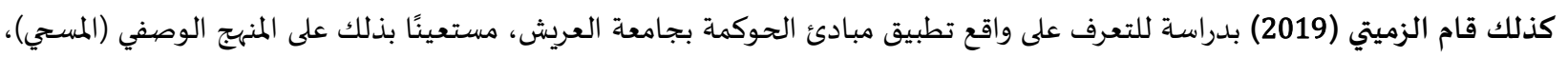

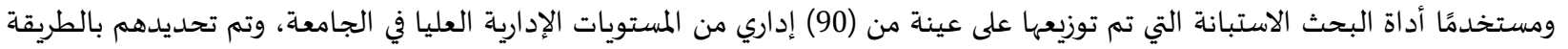


العمدية أولاً، وبعد ذلك تم الاختيار منهم بالطريقة العشوائية. وقدم نتائج دراسته بأن جامعة العريش تطبق مبادئ الحوكمة بمتوسط كلي

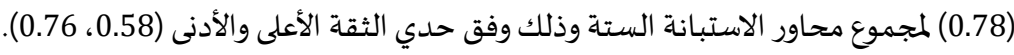
وقصيد سالمي (Salmi, 2019 في دراستاه مراجعة للحوكمة الأكاديمية والقيادية على المستويين الحكومي والخاص، مع تقديم تحليل للتطورات الجديدة في السياسات المساهمة في إصلاح التعلم العالي في فيتنام، حيث كشفت نتائج الدراسة عن وجود تغييرات فيما يتعلق بآليات الحوكمة في

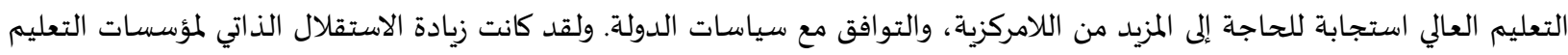

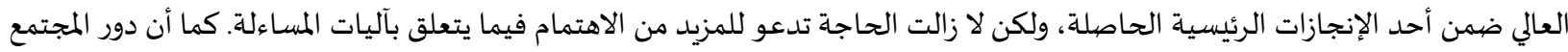

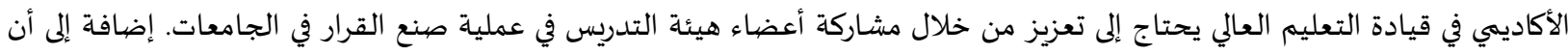
خصخصة التعليم العالي قد ساهمت بشكل كبير في تطوير التعليم العالي الحكومي.

واستهدفت دراسـة الأكلبي (2019) التعرف على واقع اليقظة الاستراتيجية، والتحقق من مستوى الحوكمة في جامعة شقراء، والتوصل إلى طبيعة

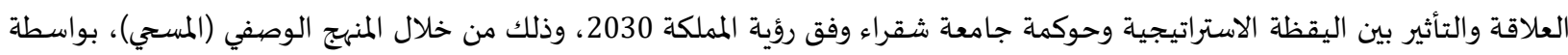

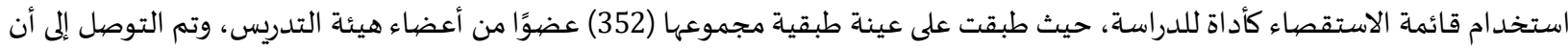

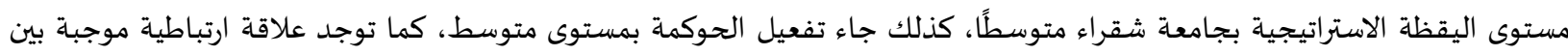

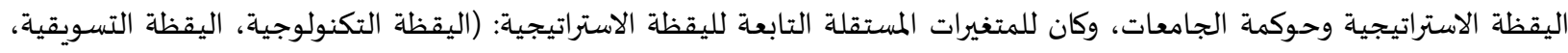

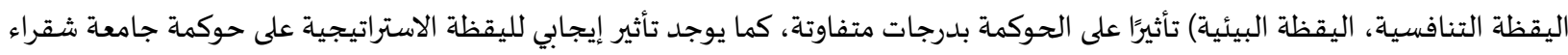
وفق رؤية المملكة 2030. وأشار حمادة (Hamada, 2019) في دراسته التي أجراها للتعرف على موقف مهنة التدريس الياباني من الإصلاحات لحوكمة المدارس،

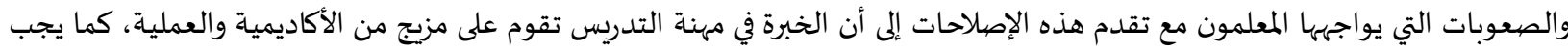

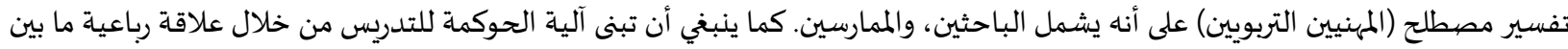
الباحثين، والممارسين، والمواطنين، والحكومة. وفي دراسـة شتات (2018) التي هدفت لاستقصاء درجة ممارسة رؤساء الأقسام الأكاديمية في الجامعات الأردنية للحوكمة، متبعة في ذلك المنهج الوصفي (المستي)، حيث تم اختيار عينة من ثلاث جامعات وفق الطريقة العنقودية، ثم اختيرت عينة مكونة من (130) عضيو من أعضاء هيئة

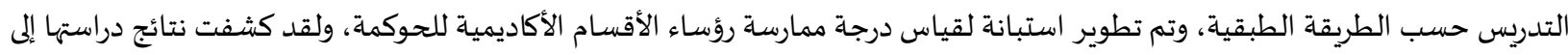
أن درجة ممارسة تطبيق الحكومة متوسطة، ولم يلحظ وجود فروق ذات دلالة إحصائية تعزى لمتغيرات: (الجنس، الدرجة العلمية، نوع الكلية)،

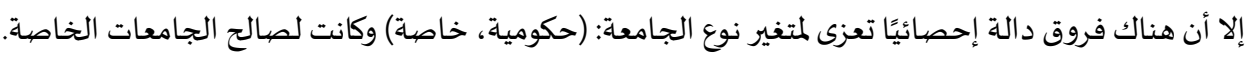
وهدف عساف (2018) في دراستـه التعرف على درجة تقدير أعضاء هيئة التدريس بالجامعات الفلسطينية لمدى تطبيق مبادئ الحوكمة فيها،

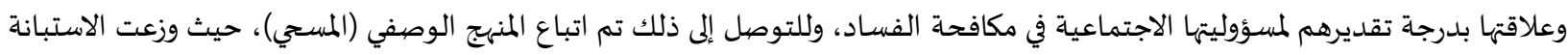

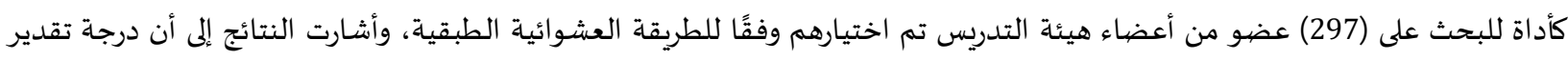

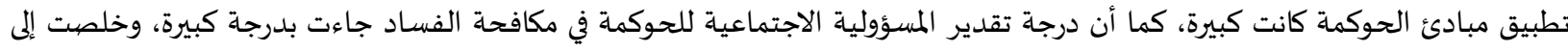

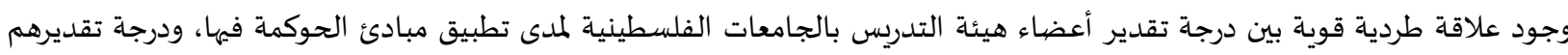
لمسؤوليتها الاجتماعية في مكافحة الفساد. وفي دراسة عسيري (2017) التي هدفت للتعرف على درجة تطبيق الحوكمة بجامعة الأمير سطام بن عبد العزيز في ضوء رؤية المملكة 2030 من

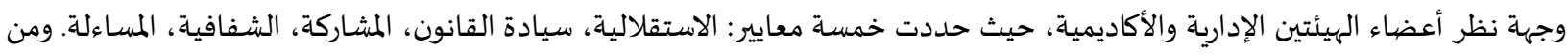

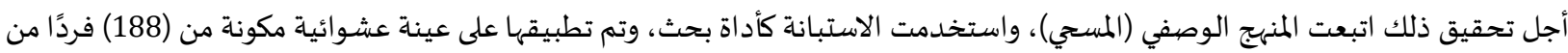

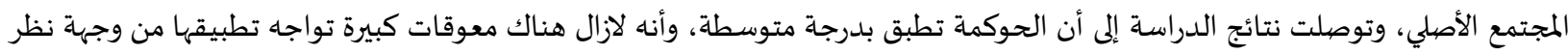

العينة.

التعقيب على الدراسـات السـابقة:

Muhsin et al., (2020) من خلال عرض الدراسات السابقة ذات العلاقة بمتغيرات الدراسة يتضح اتفاقها مع بعضها في بعض الجوانب كدراسة التهات

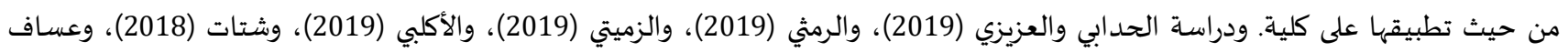

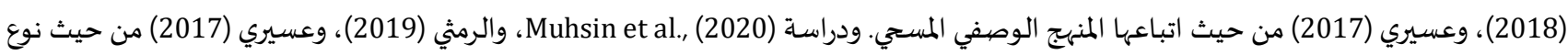
العينة العشوائية. ودراسة الرمثي (2019)، والأكلبي (2019)، وشيريتات (2018)، (2019)، وعساف (2018)، وعسيري (2017) من حيث المجتمع المتمثل من أعضياء

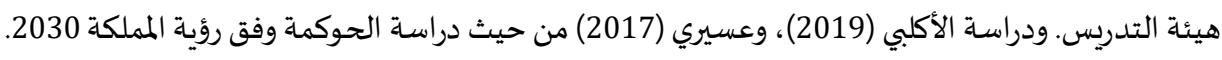




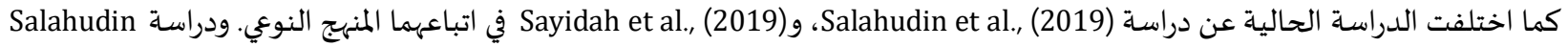

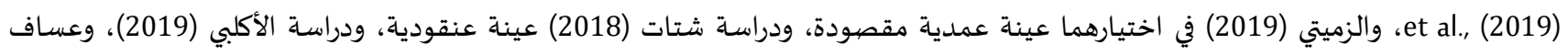
مu من حيث مجتمع البحث المتمثل بالطلاب، ودراسة (2019) (2018) عينة طبقية. ودراسة (2020) (2019) على خبراء وباحثين، ودراسة (2019) ,. Sayidah et al على رؤساء الأقسام في الجامعات، ودراسة الزميتي (2091) على موظفين الإدارة العليا في الجامعة. ودراسة Sayidah et al., في استخدام المقابلة والوثائق كأداة لجمع البيانات، ودراسة (2019) Sahudin et al., (2019) المركزة، ودراسة الأكلبي (2019) في استخدام الاستقصاء. كما اختلفت دراسة (2019) Hamada بتطبيقه على مدارس وليس على جامعات.

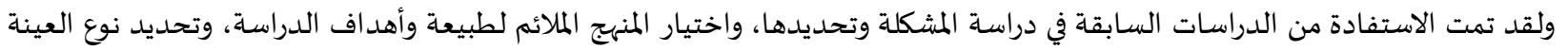
المناسب لتمثيل المجتمع الأصلي، وفي جمع الإطار النظري، وفي تفسير النتائج.

\section{منهجية الدراسة وإجراءاتها: أولاً: منهج البحث:}

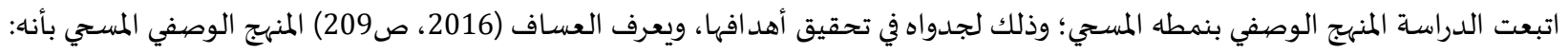

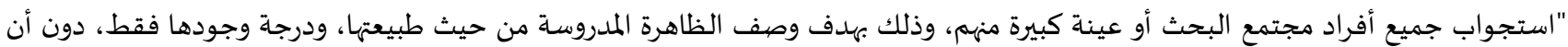
يتجاوز ذلك إلى دراسة العلاقة أو استنتاج الأسباب مثلًاً". ثانيًا: مجتمع الدراسـة: يتكون مجتمع الدراسة من جميع أعضياء هيئة التدريس في كلية التربية بجامعة القصيم البالغ عددهم 127، وذلك وفق آخر إحصيائية على موقع جامعة القصيم (جامعة القصيم، 2017). ثالثًا: عينة الدراسـة:

1. ت عينة تقنين الاستبانة (العينة الاستطلاعية):

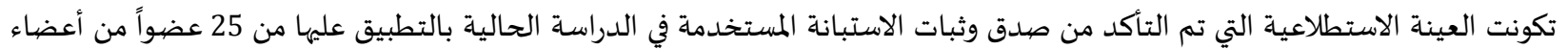

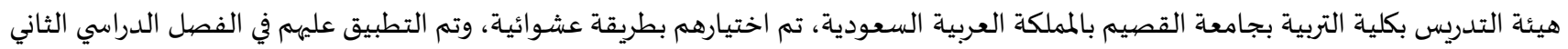
من العام الجامعي 1441هـ. 2. حسبت عينة الدراسة وفقًا لمعادلة ستيفن ثامبسون لتصبح 95 عضوًا من أعضاء هيئة التدريس بكلية التربية بجامعة القصيم، تم اختيارهم بطريقة عشوائية بسيطة من غير المشاركين في الدراسة الاستطلاعية، وتم التطبيق عليهم في الفصل الدراسي الثاني من العام الجامعي 1441هـ،

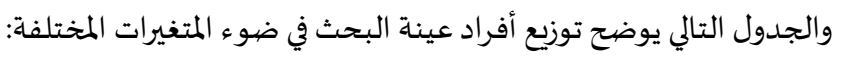
جدول (1): توزيع أفراد عينة الدراسة الأساسية في ضوء المتغيرات المختلفة

\begin{tabular}{|c|c|c|}
\hline النسبة & العدد & الجنس \\
\hline$\% 58.9$ & 56 & ذكر \\
\hline$\% 41.1$ & 39 & أنثى \\
\hline النسبة & العدد & الرتبة الأكاديمية \\
\hline$\% 41.1$ & 39 & أستاذ مساعد \\
\hline$\% 32.6$ & 31 & أستاذ مشارك \\
\hline$\% 26.3$ & 25 & أستاذ \\
\hline
\end{tabular}

يتضح من الجدول السابق أن النسبة الأكبر من أفراد عينة الدراسة الأساسية كانوا من الذكور بنسبة بلغت 58.9\%، بينما بلغت نسبة الإناث

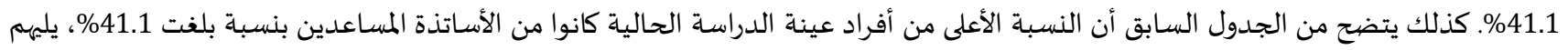

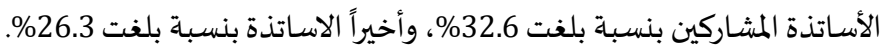
رابعًا: أدوات الدراسـة: للإجابة عن أسئلة الدراسة تم استخدام الاستبانة كأداة لجمع البيانات اللازمة من الأفراد عينة الدراسـة، فبعد أن تم الاطلاع على الدراسات

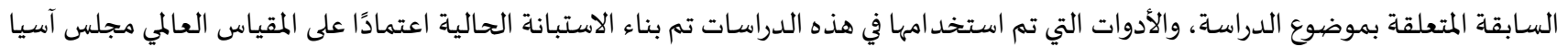


للأوراق المالية (CLSA)، بحيث تم تطويره وتكيفه لغرض ضمان تطبيق الحوكمة بالجامعات العربية بشكل موضوعي وقابل للقياس، وبما يمكن من

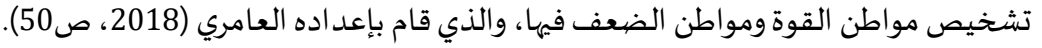

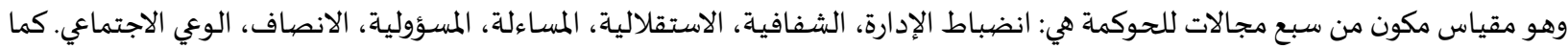
أن تدرج خيارات الإجابة جاءت وفق المقياس الرباعي بحيث يعني (1)حوكمة ضعيفة، (2)حوكمة متوسطة، (3)حوكمة جيدة، (4)حوكمة عالية. ولقد

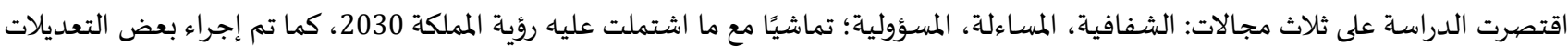
الطفيفة بشكل يمكن من تطبيقه على إدارة الكلية. وفيما يلي وصف للاستبانة المستخدمة وخصائصها الإحصائية، وكيفية الاستجابة عليها، وتحديد الدرجات.

صددق وثبات الاستبانة: 1

للتحقق من صدق الاستبانة الحالية تم الاعتماد على الصدق الظاهري (صدق المحكمين) Face Validity كما أن هذا الاستبانة بنيت أسـاسًا على

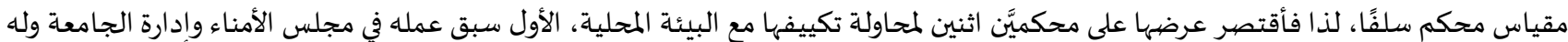
خبرة في مجال الحوكمة، والآخر مختص بالإدارة التربوية وعضيو هيئة تدريس في الوقت نفساه ليمثل بذلك العينة المستهدفة، حيث طلب منهم دراسة

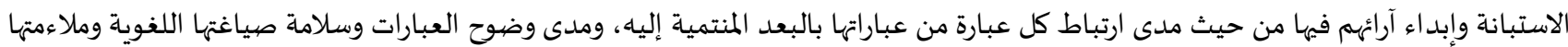

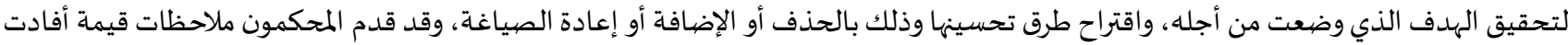
الدراسة، وأثرت الاستبانة، وساعدت على إخراجها بصورة جيدة، حيث حظيت جميع عبارات الاستبانة باتفاق غالبية المحكمين، مع بعض وضات الماتلاحظات التي تم مراعاتها في النسخة الههائية من الاستبانة، ومن هذه الملاحظات: استبدال قول إدارة الجامعة بإدارة الكلية؛ لاقتصار الدراسة على كلية التربية

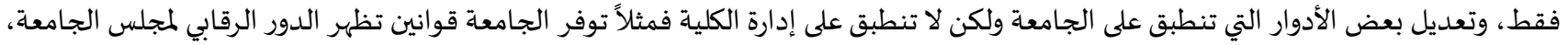
والمعروف دور إدارة الكلية يكون الإعلان عن هذه القوانين وليس توفيرها وإصدارها، كما تم تقديم إقتراح ترتيب عبارات الاستبانة وفق تسلسلها

وتم كذلك التحقق من صدق الاستبانة عن طريق صدق الاتساق الداخلي Internal Consistency وذلك باستخدام معامل ارتباط بيرسون في حساب معاملات الارتباط بين درجة كل عبارة ودرجة البعد المنتمية إليه العبارة وذلك للتأكد من مدى تماسك وتجانس عبارات كل بعد فيما بينها،

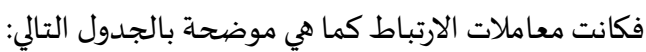

جدول (2): معاملات الارتباط بين درجات عبارات الاستبانة والدرجة الكلية للبعد المنتمية إليه العبارة

\begin{tabular}{|c|c|c|c|c|c|}
\hline الارتباط & العبارة & الارتباط & العبارة & الارتباط & العبارة \\
\hline & المسؤولية & & الشفافية & & المساءلة \\
\hline${ }^{* *} 0.772$ & 1 & ${ }^{* * 0} 0.891$ & 1 & ${ }^{* *} 0.617$ & 1 \\
\hline${ }^{* *} 0.852$ & 2 & ${ }^{* *} 0.877$ & 2 & ${ }^{* *} 0.729$ & 2 \\
\hline$* * 0.854$ & 3 & ${ }^{* *} 0.960$ & 3 & ${ }^{* *} 0.750$ & 3 \\
\hline${ }^{* *} 0.886$ & 4 & ${ }^{* *} 0.831$ & 4 & ${ }^{* *} 0.597$ & 4 \\
\hline$* * 0.770$ & 5 & ${ }^{* *} 0.913$ & 5 & ${ }^{* *} 0.798$ & 5 \\
\hline${ }^{* *} 0.854$ & 6 & ${ }^{* *} 0.864$ & 6 & $* * 0.847$ & 6 \\
\hline
\end{tabular}

يتضيح من الجدول السابق أن معاملات الارتباط بين درجات عبارات الاستبانة والدرجة الكلية للبعد المنتمية إليه العبارة جميعها معاملات ارتباط

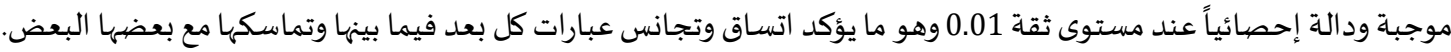

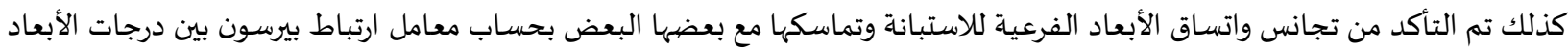

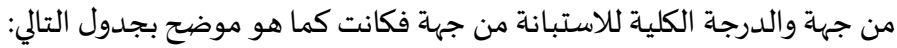
جدول (3): معاملات الارتباط بين درجات أبعاد الاستبانة والدرجة الكلية

\begin{tabular}{ccc}
\hline المساءلة & ${ }^{*} 0.840$ \\
\hline
\end{tabular}

يتضح من الجدول السـابق أن معاملات الارتباط بين درجات الأبعاد الفرعية للاستبانة والدرجة الكلية جميعها معاملات ارتباط موجبة ودالة

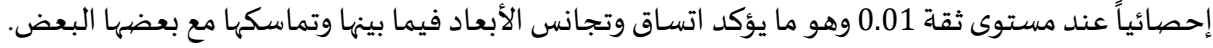


تم التحقق من ثبات درجات الاستبانة الحالية وأبعادها الفرعية باستخدام معامل ثبات ألفا كرونباخ فكانت معاملات الثبات كما هو موضح

بالجدول التالي:

\begin{tabular}{|c|c|c|c|}
\hline ثبات المحورككل: & المسؤولية: & الشفافية: & المساءلة: \\
\hline 0.946 & 0.910 & 0.940 & 0.819 \\
\hline
\end{tabular}

يتضح من الجدول السابق أن لدرجات الاستبانة وأبعادها الفرعية معاملات ثبات مرتفعة ومقبولة إحصائياً؛ ومما سبق يتضح أن للاستبانة مؤشرات إحصائية جيدة (الصيدق، الثبات) ويتأكد من ذلك صلاحية استخدامها في الدراسة الحالية للتعرف على مستوى تفعيل الحوكمة في كلية التربية بجامعة القصيم في ضوء رؤية المملكة 2030 من وجهة نظر أعضاء هيئة التدريس. ويتجب ملاحظة أنه تتم الاستجابة لعبارات الاستبانة المستخدمة في الدراسـة الحالية بأن يتم الاختيار ما بين أربعة اختيارات، تتمثل في (عالية، جيدة، متوسطاة، ضعيفة)، وتقابل الاستجابات الدرجات (4، 3، 2، 1) على الترتيب؛ والدرجة المرتفعة في أي عبارة أو بعد في الاستبانة تعبر عن درجة عالية من

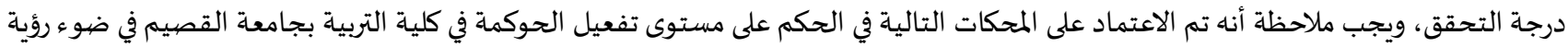

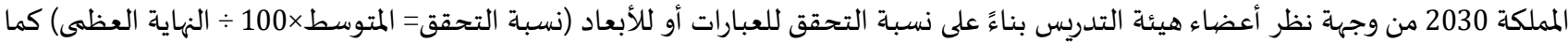

هو موضح بالجدول التالي:

جدول (5): محكات الحكم على مستوى تفعيل الحوكمة في كلية التربية بجامعة القصيم في ضوء رؤية المملكة 2030 من وجهة نظر أعضياء هيئة التدريس

\begin{tabular}{|c|c|}
\hline مستوى الحوكمة: & نسبة التحقق للعبارة أو للبعد: \\
\hline ضعيفة & أقل من 25\% \\
\hline متوسطة & من 25\% لأقل من 50\% \\
\hline جيدة ا & من 50\% لأقل من 75\% \\
\hline عالية & من 75\% فأكثر \\
\hline
\end{tabular}

خامسًا: الأساليب الإحصيائية المستخدمة: في الدراسـة الحالية تم استخدام العديد من الأساليب الإحصائية باستخدام الحزمة الإحصيائية المائية في العلوم الاجتماعية SPSS كالتالي:

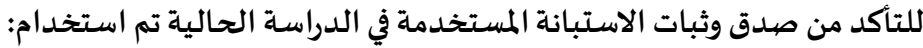

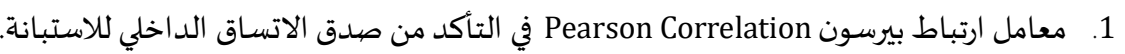
2. معامل ثبات ألفا كرونباخ Alpha Cronbach في التأكد من ثبات الاستبانة.

للإجابة عن أسئلة الدراسـة تم استخدام:

1. التكرارات Prequencies والنسب المئوية Pent والمتوسطات Mean والانحرافات المعيارية Std. Deviation في الكشف عن مستوى تفعيل

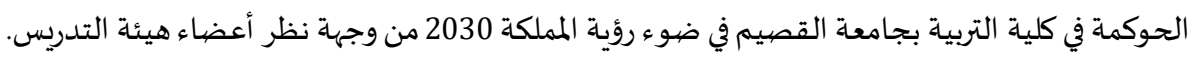

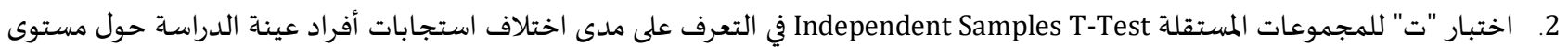
تفعيل الحوكمة في كلية التربية بجامعة القصيم في ضوء رؤية المملكة 2030 من وجهة نظر أعضاء هيئة التدريس والتي ترجع لاختلاف متغير (الجنس).

3. اختبار تحليل التباين أحادي الاتجاه One Way ANOVA في التعرف على مدى اختلاف استجابات أفراد عينة الدراسة حول مستوى تفعيل الحوكمة في كلية التربية بجامعة القصيم في ضوء احتيل رؤية المملكة 2030 من وجهادة نظر أعضاء هيئة التدريس والتي ترجع لاختلاف متغير (الرتبة

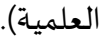

\section{نتائج الدراسـة ومناقشتها:} نتائج إجابة السؤال الأول: ينص السؤال الأول على "ما مستوى تفعيل الحوكمة في كلية التربية بجامعة القصيم في ضوء رؤية المملكة 2030 من وجهة نظر أعضياء هيئة التدريس؟ إجابه للإجابة عن هذا السؤال تم حساب التكرارات والنسب المئوية لاستجابات أفراد عينة الدراسة على كل عبارة من عبارات الاستبانة والمتعلقة بمستوى تفعيل الحوكمة في كلية التربية بجامعة القصيم في ضوء رؤية المملكة 2030 من وجهة نظر أعضياء هيئة التدريس، ثم تم حساب المتوسطات والانحرافات المعيارية لهذه الاستجابات وكذلك نسبة التحقق لكل عبارة وذلك لتحديد درجة تحقق كل عبارة من هذه العبارات، فكانت النتائج كما هي موضحة في التالي: 


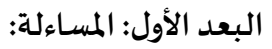

جدول (6): التكرارات والنسب المئوية والمتوسطات والانحر افات المعيارية لاستجابات عينة الدراسة حول مستوى تفعيل الحوكمة في كلية التربية بجامعة

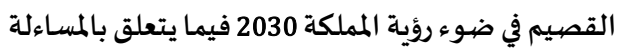

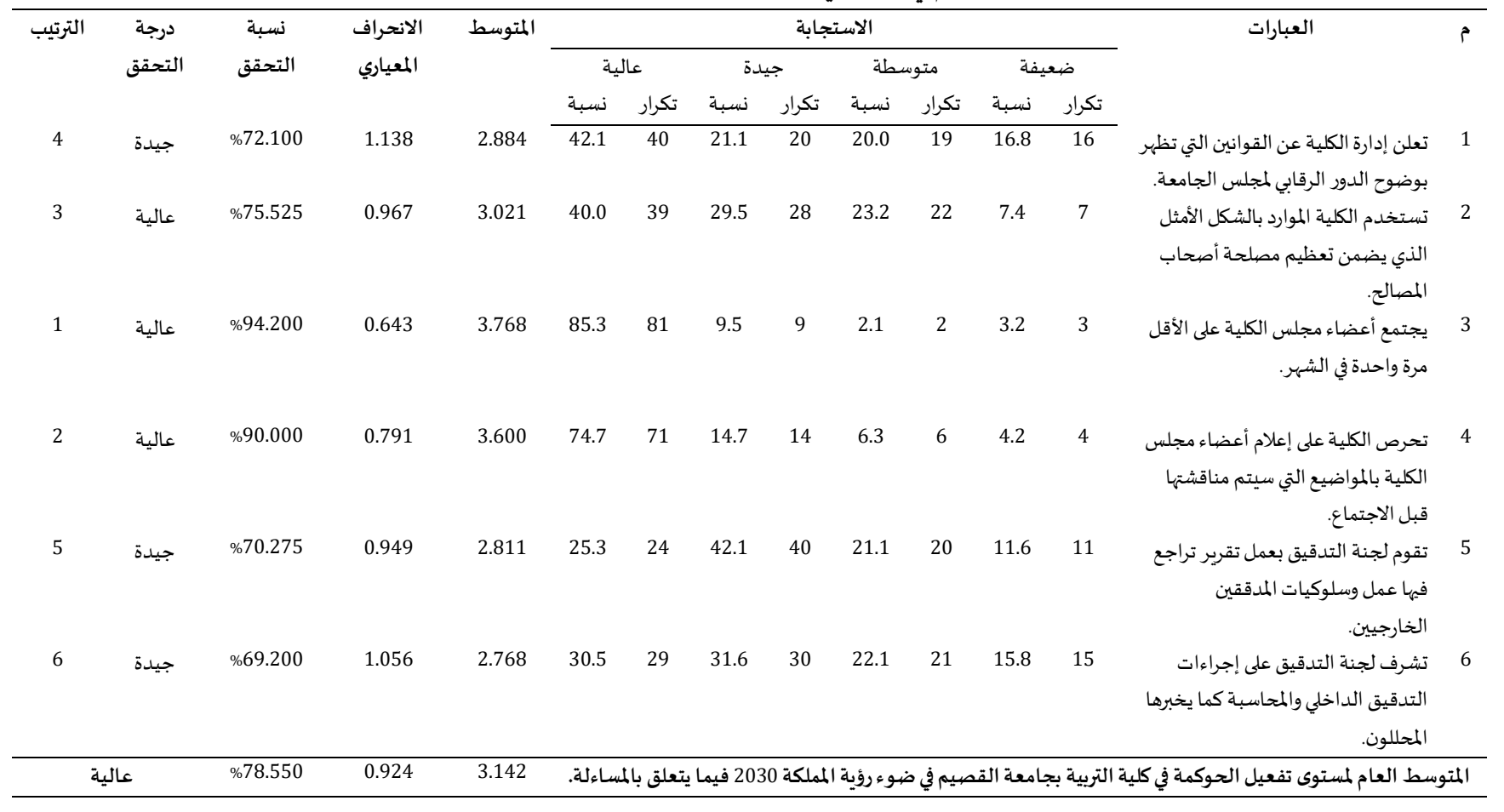

يتضح من الجدول السابق أن:

مستوى تفعيل الحوكمة في كلية التربية بجامعة القصيم في ضوء الجولية رؤية المملكة 2030 من وجهة نظر أعضاء هيئة التدريس فيما يتعلق بالمساءلة مت

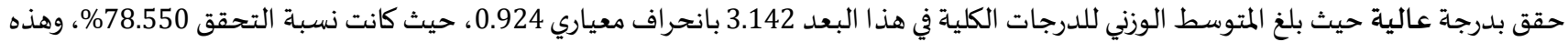

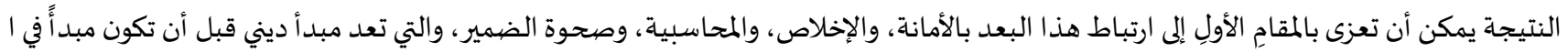

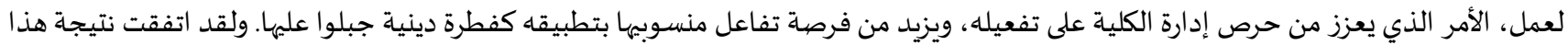

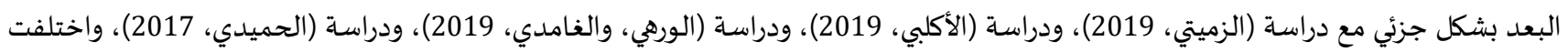
مع دراسة (الدهدار، والفرا، 2017). ودراسة (الزايدي، 2019).أما بشأن العبارات الفرعية في هذا البعد فجاءت مرتبة حسب أعلى عبارتين وأقل عبارتين كما يلي:

جاءت العبارة "يجتمع أعضاء مجلس الكلية على الأقل مرة واحدة في الشهر" في الترتيب الأول من حيث درجة التحقق، ومتحققة بدرجة عالية حيث بلغت قيمة متوسط استجابات أفراد عينة الدراسة حول هذه العبارة 3.768 بانحراف معياري قدره جاءت العبارة "تحرص الكلية على إعلام أعضاء مجلس الكلية بالمواضيع التي سيتم مناقشتها قبل الاجتماع" في الترتيب الثاني من حيث درجة التحقق، ومتحققة بدرجة عالية حيث بلغت قيمة متوسط استجابات أفراد عينة الدراسة حول هذه العباء اعبارة 3.600 بانحراف معياري قدره 0.791 جاءت العبارة "تقوم لجنة التدقيق بعمل تقرير تراجع فيها عمل وسلوكيات المدققين الخارجيين" في الترتيب الخامس من حيث درجة التحقق، ومتحققة بدرجة جيدة حيث بلغت قيمة متوسط استجابات أفراد عينة الدراسة حول هذه العبارة 2.811 بانحراف معياري قدره 0.949. جاءت العبارة "تشرف لجنة التدقيق على إجراءات التدقيق الداخلي والمحاسبة كما يخبرها المحللون" في الترتيب السادس من حيث درجة التحقق، ومتحققة بدرجة جيدة حيث بلغت قيمة متوسط استجابات أفراد عينة الدراسة حول هذه العبارة 2.768 بانحراف معياري قدره .1 .056 ويمكن توضيح مستوى تفعيل الحوكمة في كلية التربية بجامعة القصيم في ضوء رؤية المملكة 2030 من وجهاة نظر أعضاء هيئة التدريس فيما يتعلق بالمساءلة من خلال الشكل التالي: 


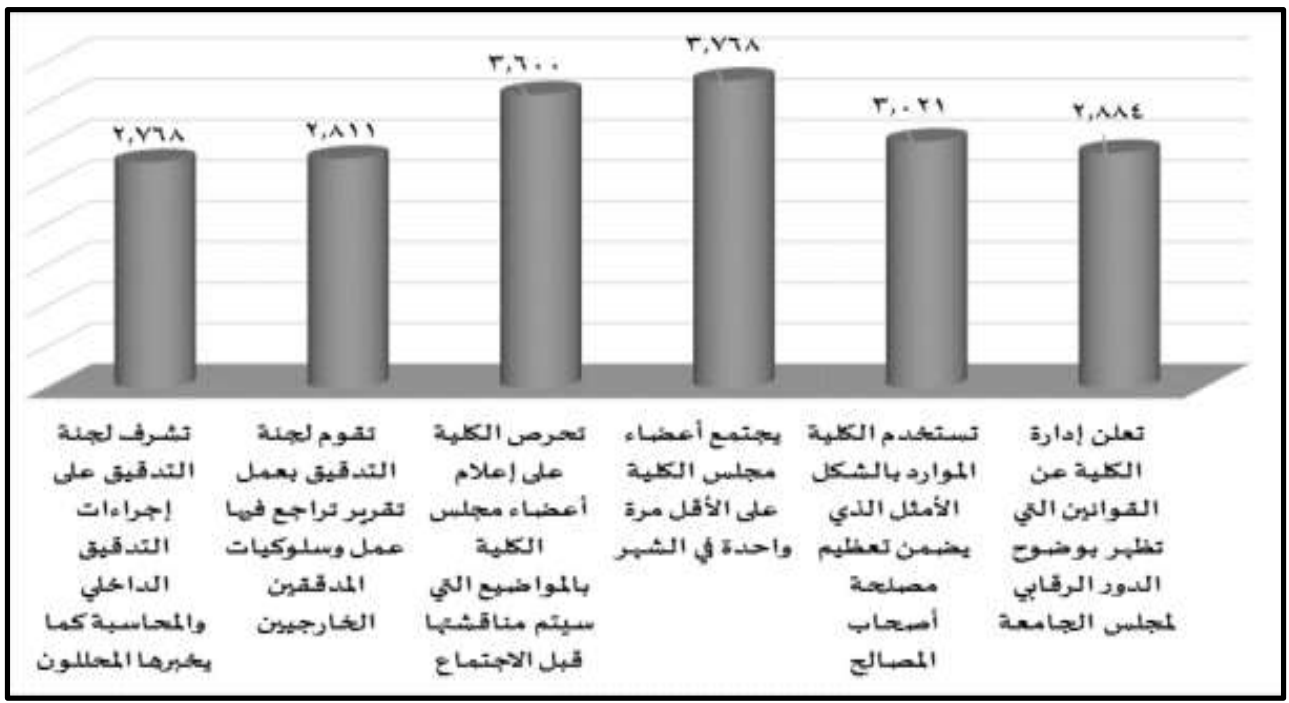

شكل (2): مستوى تفعيل الحوكمة في كلية التربية بجامعة القصيم في ضوء رؤية المملكة 2030 فيما يتعلق بالمساءلة

البعد الثاني: الشفافية:

جدول (7): التكرارات والنسب المئوية والمتوسطات والانحر افات المعيارية لاستجابات عينة الدراسة حول مستوى تفعيل الحوكمة في كلية التربية بجامعة

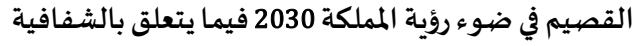

\begin{tabular}{|c|c|c|c|c|c|c|c|c|c|c|c|c|c|c|}
\hline \multirow[t]{3}{*}{ الترتيب } & \multirow{3}{*}{ التحقق } & \multirow{3}{*}{ التحقق } & \multirow{3}{*}{ 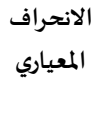 } & \multirow[t]{3}{*}{ المتوسط } & \multicolumn{8}{|c|}{ الاستجابة } & \multirow[t]{3}{*}{ العبارات } & p \\
\hline & & & & & \multicolumn{2}{|c|}{ عالية } & \multicolumn{2}{|c|}{ جيدة } & \multicolumn{2}{|c|}{ متوسطة } & \multicolumn{2}{|c|}{ ضعيفة } & & \\
\hline & & & & & نسبة & تكرار & نسبة & تكرار & نسبة & تكرار & نسبة & تكرار & & \\
\hline 1 & عالية & $\% 80.800$ & 0.844 & 3.232 & 45.3 & 43 & 36.8 & 35 & 13.7 & 13 & 4.2 & 4 & توضح الكلية لإداراتها أهداف أصحاب & 1 \\
\hline 6 & جيدة & $\% 66.325$ & 1.050 & 2.653 & 26.3 & 25 & 29.5 & 28 & 27.4 & 26 & 16.8 & 16 & تصليدر إدارة الكلية تقريرها السنوي & 2 \\
\hline 3 & جيدة & $\% 70.275$ & 1.085 & 2.811 & 34.7 & 33 & 27.4 & 26 & 22.1 & 21 & 15.8 & 15 & 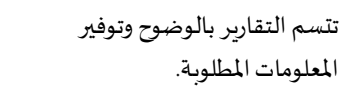 & 3 \\
\hline 4 & جيدة & $\% 68.150$ & 1.171 & 2.726 & 34.7 & 33 & 26.3 & 25 & 15.8 & 15 & 23.2 & 22 & تحترص إدارة الكلية على إصدار نتائج & 4 \\
\hline 2 & جيدة & $\% 71.575$ & 0.985 & 2.863 & 34.7 & 33 & 24.2 & 23 & 33.7 & 32 & 7.4 & 7 & تعسب إدارة الكلية كشوفاتها المالية & 5 \\
\hline 5 & جيدة & $\% 67.375$ & 1.022 & 2.695 & 26.3 & 25 & 31.6 & 30 & 27.4 & 26 & 14.7 & 14 & تفصح إدارة الكلية عن نتائج الأداء & 6 \\
\hline & & $\% 70.750$ & 1.026 & 2.830 & & فيما يتعا & كة 2030 & رؤية الم & في ضر & ةُ القص & 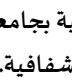 & كلية الت & المتوسط العام لمستوى تفعيل الحوكمة & \\
\hline
\end{tabular}

يتضح من الجدول السابق أن: مستوى تفعيل الحوكمة في كلية التربية بجامعة القصييم في ضوء رؤية المملكة 2030 من وجهة نظر أعضاء هيئة التدريس فيما يتعلق بالشفافية

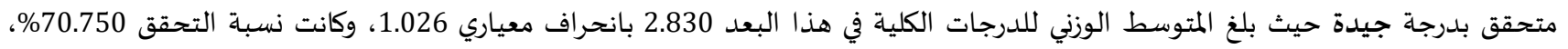

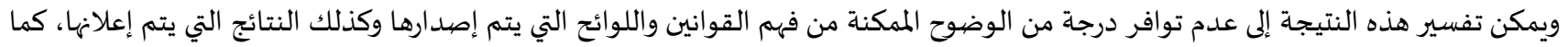

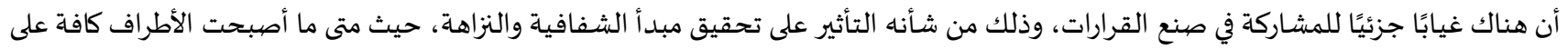

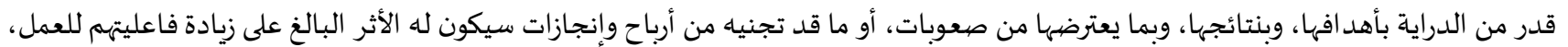

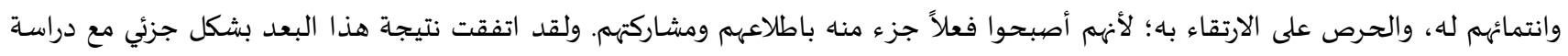

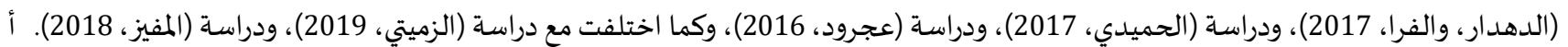
ما بشأن العبارات الفرعية في هذا البعد فجاءت مرتبة حسب أعلى عبارتين وأقل عبارتين كما يلي: 
جاءت العبارة "توضح الكلية لإداراتها أهداف أصحاب المصالح المستهدفة" في الترتيب الأول من حيث درجة التحقق، ومتحققة بدرجة عالية حيث بلغت قيمة متوسط استجابات أفراد عينة الدراسة حول هذه العبارة 3.232 بانحراف معياري قدره 0.844.

جاءت العبارة "تعد إدارة الكلية كشوفاتها المالية بحسب معايير المحاسبة المقبولة قبولاً عامًا" في الترتيب الثاني من حيث درجة التحقق، ومتحققة بلدرجة جيدة حيث بلغت قيمة متوسط استجابات أفراد عينة الدراسة حول هذه العبارة 2.863 بانحراف معياري قدره 0.985. جاءت العبارة "تفصح إدارة الكلية عن نتائج الأداء وانعكاساتها على أصحاب المصالح كافة" في الترتيب الخامس من حيث درجة التحقق، ومتحققة بدرجة جيدة حيث بلغت قيمة متوسط استجابات أفراد عينة الدراسة حول هذه العبارة 2.695 بانحراف معياري قدره 1.022. جاءت العبارة "تصدر إدارة الكلية تقريرها السنوي ضهمن الأربعة الأشهر الأخيرة من السنة المالية" في الترتيب السادس من حيث درجة التحقق، ومتحققة بدرجة جيدة حيث بلغت قيمة متوسط استجابات أفراد عينة الدراسة حول هذه العبارة 2.653 بانحراف معياري قدره 1.050.

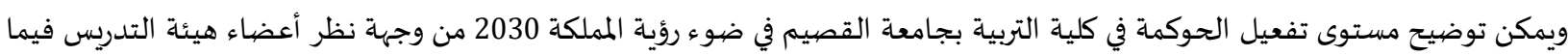
يتعلق بالشفافية من خلال الشكل التالي:

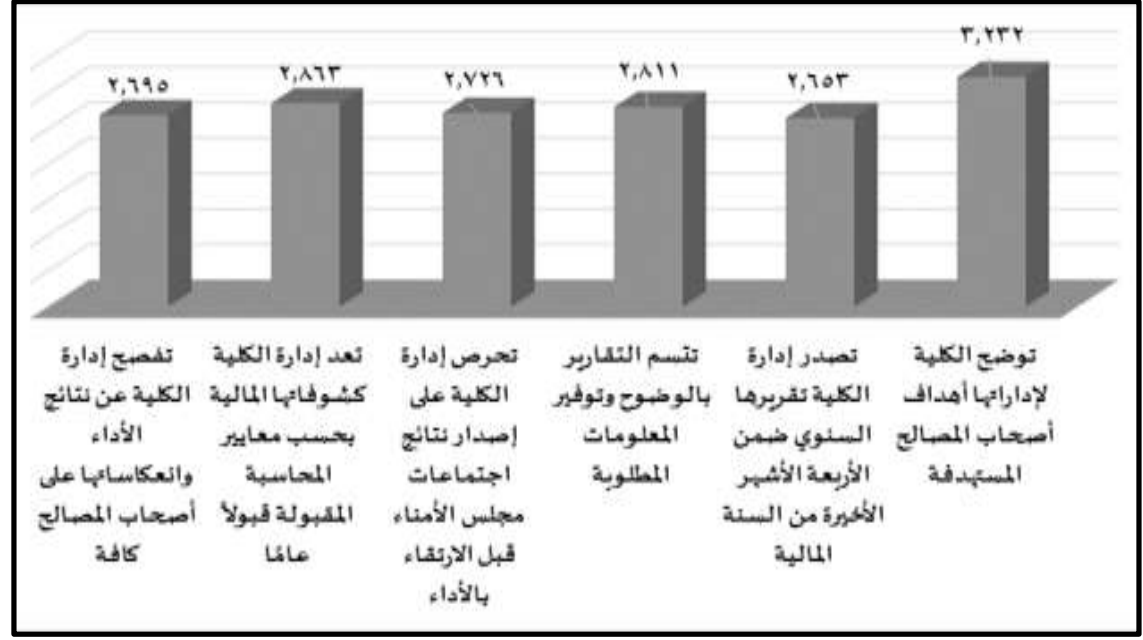

شكل (3): مستوى تفعيل الحوكمة في كلية التربية بجامعة القصيم في ضهوء رؤية المملكة 2030 فيما يتعلق بالشفافية

البعد الثالث: المسؤولية:

جدول (8): التكرارات والنسب المئوية والمتوسطات والانحر افات المعيارية لاستجابات عينة الدراسة حول مستوى تفعيل الحوكمة في كلية التربية بجامعة القصيم في ضوء رؤية المملكة 2030 فيما يتعلق بالمسؤولية

\begin{tabular}{|c|c|c|c|c|c|c|c|c|c|c|c|c|}
\hline \multirow[t]{3}{*}{ الترتيب } & \multirow{3}{*}{ التحقق درجة } & \multirow{3}{*}{ نسبة } & \multirow{3}{*}{ الالنحراف } & \multirow[t]{3}{*}{ المتوسط } & \multicolumn{8}{|c|}{ الاستجابة } \\
\hline & & & & & \multicolumn{2}{|c|}{ عالية } & \multicolumn{2}{|c|}{ جيدة } & \multicolumn{2}{|c|}{ متوسطة } & \multicolumn{2}{|c|}{ ضعيفة } \\
\hline & & & & & نسبة & تكرار & نسبة & تكرار & نسبة & تكرار & نسبة & تكرار \\
\hline 4 & جيدة & $\% 68.950$ & 1.049 & 2.758 & 33.7 & 32 & 20.0 & 19 & 34.7 & 33 & 11.6 & 11 \\
\hline 2 & جيدة & $\% 74.200$ & 1.143 & 2.968 & 48.4 & 46 & 14.7 & 14 & 22.1 & 21 & 14.7 & 14 \\
\hline 6 & جيدة & $\% 65.525$ & 1.132 & 2.621 & 29.5 & 28 & 25.3 & 24 & 23.2 & 22 & 22.1 & 21 \\
\hline 3 & جيدة & $\% 70.525$ & 1.158 & 2.821 & 38.9 & 37 & 24.2 & 23 & 16.8 & 16 & 20.0 & 19 \\
\hline 1 & عالية & $\% 83.675$ & 0.908 & 3.347 & 56.8 & 54 & 28.4 & 27 & 7.4 & 7 & 7.4 & 7 \\
\hline 5 & جيدة & $\% 67.900$ & 1.127 & 2.716 & 33.7 & 32 & 23.2 & 22 & 24.2 & 23 & 18.9 & 18 \\
\hline
\end{tabular}

هناك إجراءات تضمن عدم تعارض مصالح الكلية مع مصالح الشركاء الرئسيسن. هناك آليات تضمن الشفافية والنزاهة في قرارات مجلس الكلية. 3 المسؤولين عن اتخاذ قرارات لمصلحتهم على حساب مصالح الآخرين. 4 المسؤولين عن حدوث الأخطاء الإدارية. 5

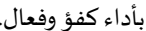
6 السلوكيات والممارسات الخاطئة وتحديد المسؤولين عنها.

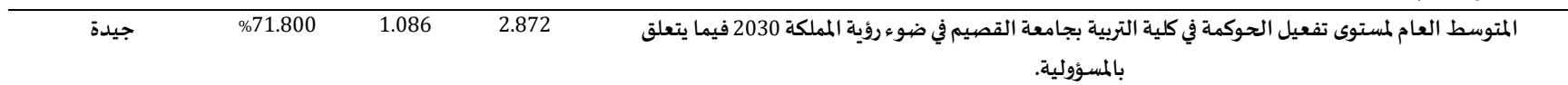




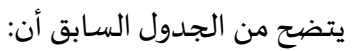

مستوى تفعيل الحوكمة في كلية التربية بجامعة القصييم في ضوء رؤية المملكة 2030 من وجهة نظر أعضاء هيئة التدريس فيما يتعلق بالمسؤولية

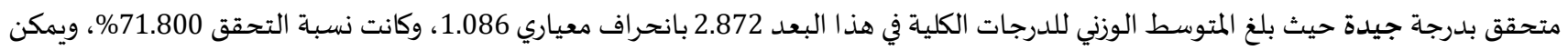

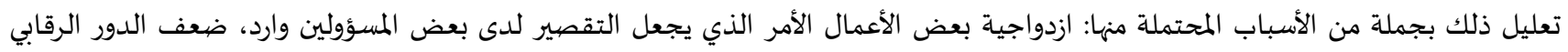

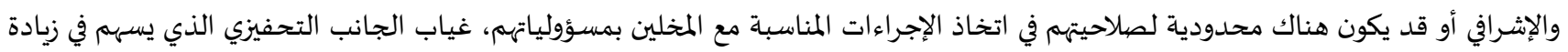

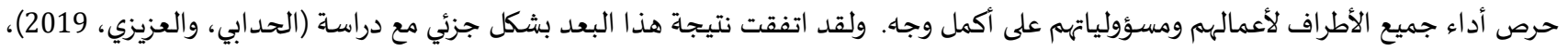

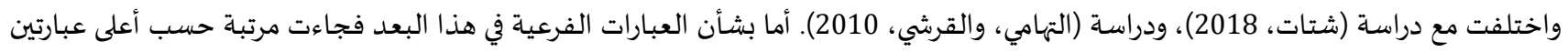
وأقل عبارتين كما يلي:

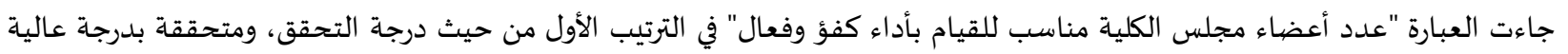

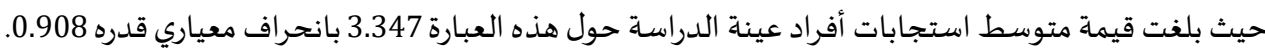

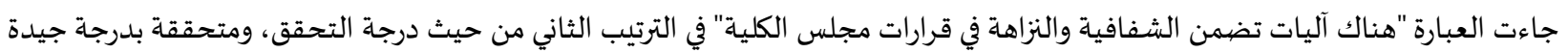

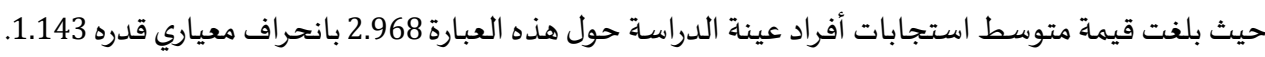

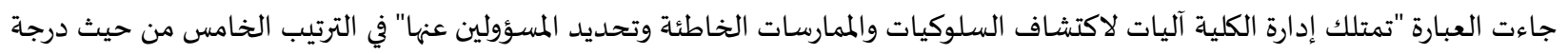

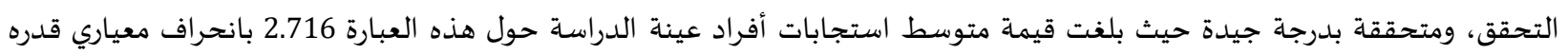

هاءت العبارة "تعدل إدارة الكلية سلوكيات الأفراد المسؤولين عن اتخاذ قرارات لمصلحتهم على حساب مصالح الآخرين" في الترتيب السادس من

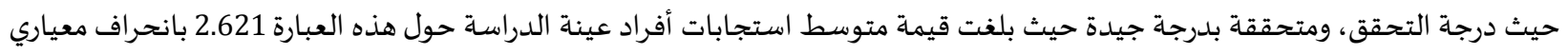
قدره 1.132. ويمكن توضيح مستوى تفعيل الحوكمة في كلية التربية بجامعة القصيم في ضوء رؤية المملكة 2030 من وجهاة نظر أعضاء هيئة التدريس فيما يتعلق بالمسؤولية من خلال الشكل التالي:

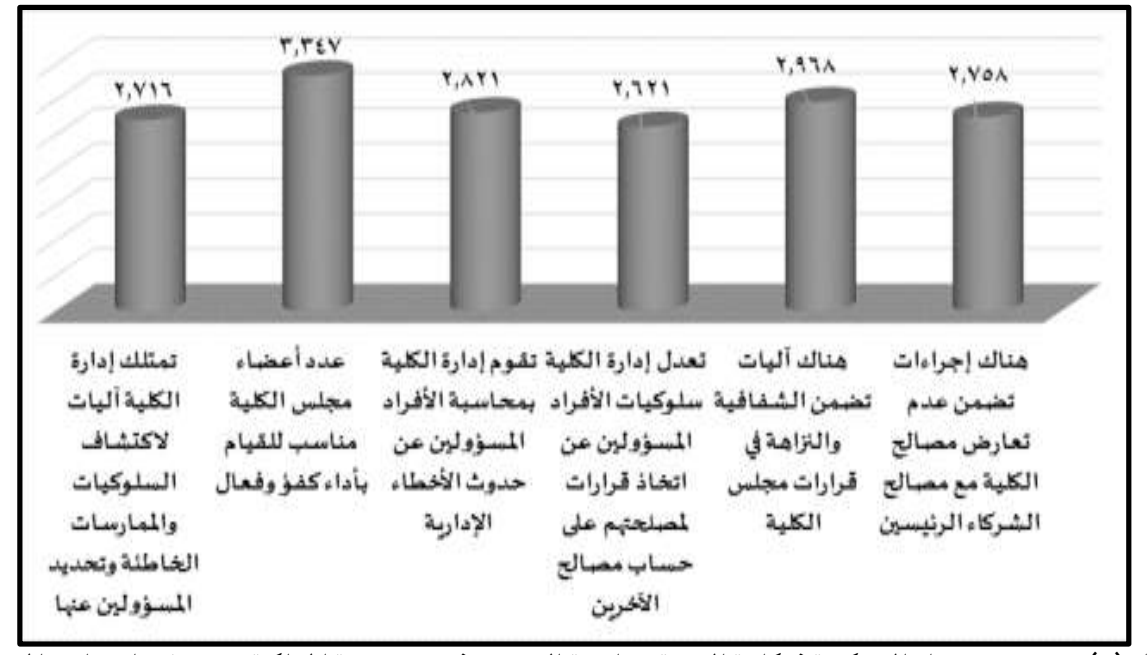

شكل (4): مستوى تفعيل الحوكمة في كلية التربية بجامعة القصيم في ضوء رؤية المملكة 2030 فيما يتعلق بالمسوؤلية.

ومجمل ما تم التوصل إليه من نتائج في إجابة السؤال الأول للدراسة الحالية والمتعلق بمستوى تفعيل الحوكمة في كلية التربية بجامعة القصييم في

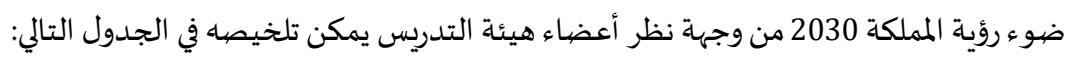

\begin{tabular}{|c|c|c|c|c|c|}
\hline الترتيب & درجة التحقق & نسبة التحقق & الانحراف المعياري & المتوسط الوزني & مستوى تفعيل الحوكمة في كلية \\
\hline 1 & عالية & $\% 78.550$ & 0.924 & 3.142 & المساءلة \\
\hline 3 & جيدة ال & $\% 70.750$ & 1.026 & 2.830 & الشفافية \\
\hline 2 & جيدة ا & $\% 71.800$ & 1.086 & 2.872 & المسؤولية \\
\hline & جيدة ل & $\% 73.700$ & 1.012 & 2.948 & مستوى تفعيل الحوكمة في كلية \\
\hline
\end{tabular}


يتضح من الجدول السابق أن مستوى تفعيل الحوكمة في كلية التربية بجامعة القصيم في ضوء رؤية المملكة 2030 من وجهة نظر أعضاء هيئة

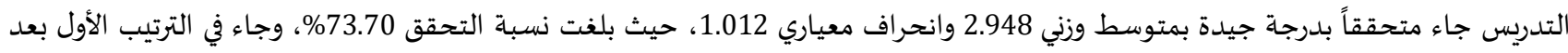

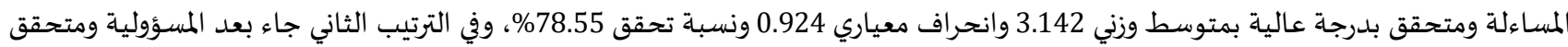
بدرجة جيدة بمتوسط وزني 2.872 وانحراف معياري 1.086 ونسبة تحقق 71.80\%، وفي الترتيب الثالث جاء بعد الشفافية ومتحقق بدرجة جيدة

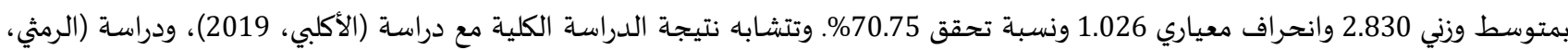
2019)، ودراسة (الحميدي، 2017)، ودراسة (نصار، 2015)، وتختلف مع دراسة (الدهدار، والفرا، 2017)، ودراسة (الزميتي، 2019)، ودراسية ودراسة (المفيز،

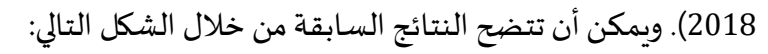

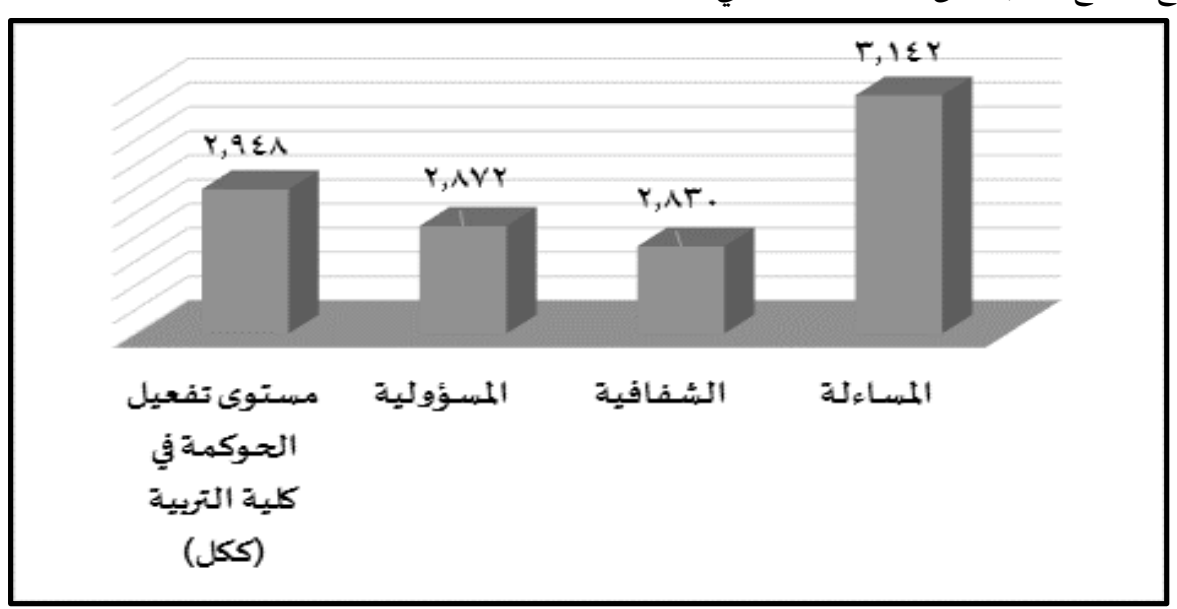

شكل (5): مستوى تفعيل الحوكمة في كلية التربية بجامعة القصيم في ضوء رؤية المملكة 2030 من وجهة نظر أعضاء هيئة التدريس

نتائج إجابة السؤال الثاني: ينص السؤال الثاني على "هل توجد فروق ذات دلالة إحصائية بين متوسط إجابات أعضياء هيئة التدريس التي تعزى لمتغيرات الدراسة: (الجنس، الرتبة العلمية)؟ 1 1 بالنسبة لمتفير الجنس:

تم استخد ام اختبار "ت" للمجموعات المستقلة Independent Samples T-Test في الكشف عن دلالة الفروق في استجابات أفراد عينة الدراسة حول مستوى تفعيل الحوكمة في كلية التربية بجامعة القصيم في ضوء رؤية المملكة 2030 والتي ترجع لاختلاف الجنس (ذكور، إناث) فكانت النتائج كما هي موضحة في التالي:

جدول (10): دلالة الفروق في استجابات أفراد عينة الدراسة حول مستوى تفعيل الحوكمة في كلية التربية بجامعة القصيم في ضهوء رؤية المملكة 2030 باختلاف الجنس (درجات الحرية = 93)

\begin{tabular}{|c|c|c|c|c|c|}
\hline مستوى الدلالة & قيمة "ت" & الانحراف المعياري & المتوسط الحسابي & 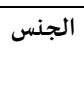 & تفعيل الحوكمة في كلية التربية بجامعة \\
\hline \multirow[t]{2}{*}{0.01} & 4.752 & 3.313 & 20.304 & 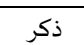 & المساءلة \\
\hline & & 3.903 & 16.769 & أنثى & \\
\hline \multirow[t]{2}{*}{0.01} & 2.956 & 4.890 & 18.286 & 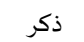 & الشفافية \\
\hline & & 5.534 & 15.103 & أنثى & \\
\hline \multirow[t]{2}{*}{0.01} & 2.844 & 5.142 & 18.500 & ل فكر & 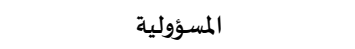 \\
\hline & & 5.305 & 15.410 & 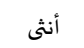 & \\
\hline \multirow[t]{2}{*}{0.01} & 3.693 & 12.414 & 57.089 & 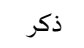 & تفعيل الحوكمة في كلية التربية بجامعة \\
\hline & & 13.183 & 47.282 & أنثى & القصيم (الدرجة الكلية) \\
\hline
\end{tabular}

يتضع من الجدول السابق أنه:

توجد فروق دالة إحصائيًا عند مستوى 0.01 في استجابات أفراد عينة الدراسة حول مستوى تفعيل الحوكمة في كلية التربية بجامعة القصيم في

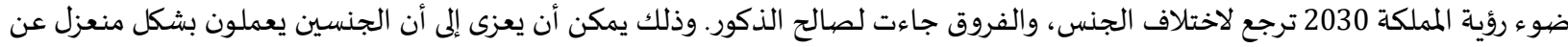

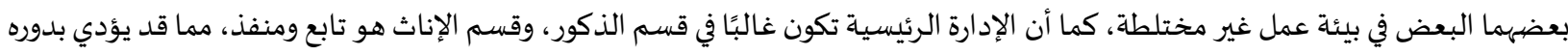

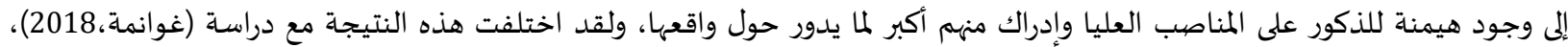

ودراسة (شتات، 2018)، ودراسة (العتيبي، 2018). 
2. - 2 بالنسبة لمتغير الرتبة العلمية:

تم استخدام اختبار تحليل التباين أحادي الاتجاه One Way ANOVA في الكشف عن دلالة الفروق ف استجابات أفراد عينة الدراسة حول مستوى تفعيل الحوكمة في كلية التربية بجامعة القصيم في ضيوء رؤية المملكة 2030 والتي ترجع لاختلاف الرتبة العلمية (أستاذ مساعد، أستاذ مشارك، أستاذ) فكانت النتائج كما هي موضحة في التالي:

\begin{tabular}{|c|c|c|c|c|c|c|}
\hline \multicolumn{6}{|c|}{ الرتبة العلمية } & \multirow{3}{*}{ فتريبل الحوكمة في كلية } \\
\hline \multicolumn{2}{|c|}{ أستاذ } & \multicolumn{2}{|c|}{ أستاذ مشارك } & \multicolumn{2}{|c|}{ أستاذ مساعد } & \\
\hline انحراف معياري & متوسط & انحراف معياري & متوسط & انحراف معياري & متوسط & \\
\hline 3.476 & 19.000 & 3.924 & 19.000 & 4.338 & 18.641 & المساءلة \\
\hline 4.776 & 18.160 & 4.998 & 16.613 & 5.999 & 16.513 & الشفافية \\
\hline 4.664 & 17.800 & 5.229 & 17.161 & 6.045 & 16.923 & المسؤولية \\
\hline 11.592 & 54.960 & 12.709 & 52.774 & 15.467 & 52.077 & (الدرجة الكلية) \\
\hline
\end{tabular}

جدول (12): دلالة الفروق في استجابات أفراد عينة الدراسة حول مستوى تفعيل الحوكمة في كلية التربية بجامعة القصيم في ضوءء رؤية المملكة 2030 باختلاف الرتبة العلمية

\begin{tabular}{|c|c|c|c|c|c|c|}
\hline مستوى الدلالة & قيمة "ف" & متوسط المربعات & درجات الحرية & مجموع المربعات & مصبدر التباين & تفعيل التحبية بجامعة القصيمة فلية \\
\hline \multirow{3}{*}{ غير دالة } & 0.093 & 1.481 & 2 & 2.962 & بين المجموعات & المساءلة \\
\hline & & 15.945 & 92 & 1466.974 & داخل المججموعات & \\
\hline & & & 94 & 1469.937 & الكلي & \\
\hline \multirow{3}{*}{$\begin{array}{l}0.444 \\
\text { غير دالة }\end{array}$} & 0.820 & 23.750 & 2 & 47.499 & بين المجموعات & الشفافية \\
\hline & & 28.962 & 92 & 2664.458 & داخل المجموعات & \\
\hline & & & 94 & 2711.958 & الكلي & \\
\hline \multirow{3}{*}{ غير دالة } & 0.201 & 5.971 & 2 & 11.942 & بين المجمموعات & المسؤولية \\
\hline & & 29.684 & 92 & 2730.963 & داخل المجموعات & \\
\hline & & & 94 & 2742.905 & الكلي & \\
\hline 0.706 & 0.350 & 65.236 & 2 & 130.472 & بين المجموعات & تفعيل الحوكمة في كلية \\
\hline \multirow[t]{2}{*}{ غير دالة } & & 186.534 & 92 & 17161.149 & داخل المجموعات & التربية بجامعة القصيم \\
\hline & & & 94 & 17291.621 & الكلي & (الدرجة الكلية) \\
\hline
\end{tabular}

يتضح من الجدول السابق أنه:

ه لا توجد فروق دالة إحصائيًا في استجابات أفراد عينة الدراسة حول مستوى تفعيل الحوكمة في كلية التربية بجامعة القصيم في ضوء رؤية

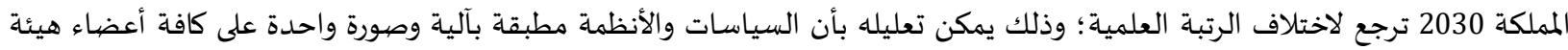
التدريس دون النظر لمرتبتهم العلمية، حيث اتفقت هذه النتيجة مع دراسة (غوانمة، 2018)، ودراسة (الحميدي، 2017)، ودراسة (شتات،

(2018

نتائج إجابة السؤال الثالث: ينص السؤال الثالث على "ما المقترحات الممكنة لتفعيل الحوكمة في كلية التربية بجامعة القصيم في ضوء رؤية

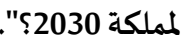
للإجابة على هذا السؤال تمت مراجعة نتائج الدراسة الحالية، مع الأخذ بعين الاعتبار الوقوف على ما يتضح فيه جوانب قصهور، ومحاولة تقديم ما يمكن من مقترحات قد تسهم في معالجتاه وتحسينه، ويمكن ذكرها في النقاط التالية:

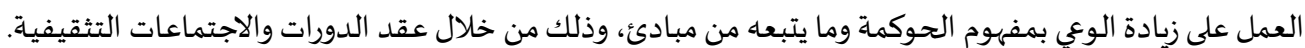
توفير وسائل اتصال فعّالة ومتعددة بين إدارة الكلية وكافة المسؤولين، وبشكل يضمن سهولة تعميم القوانين واللوائح أولًا بأول. تفعيل دور لجان التدقيق والمراقبة الداخلية والخارجية، ومساعدتهم في تهيئة الظروف الملائمة للقيام بأعمالهم ومنها: توفير عدد كافي من الموظفين المدققين بشكل لا يسبب عبء عليهم مما يحدث قصور نتيجة ضغط العمل، وتهم وتمكينهم من جدولة زياراتهم الرقابية كما يرونه مناسب، وتوفير الدعم المالي لهم، ومنحهم الصيلاحيات في إعلان النتائج مهما كان مستواها، والأخذ بما يقرونه من تحسينات للأوضاع. إصدار لوائح وأنظمة تضمن تحقق مبدأ الوضهوح والشفافية لدى إدارة الكلية، وذلك يمكن تطبيقاه من خلال: إعلانها عن نتائج أدائها ومدى ما 
حققته من أهداف لها وللأطراف الأخرى، وكذلك تصريحها عن كشوفاتها المالية، ونتائج اجتماعات مجلس الأمناء، واتباعها في تقاريرها نهج واضح

يوفر المعلومات الصيادقة والمطلوبة.

تقنين عقوبات جادّة وصارمة لمحاسبة الأفراد الذين يستخدمون سلطاتهم في تحقيق مصالحهم الخاصة على حساب مصالح الأطراف الآخرين. فصل أعمال الأقسام الإدارية عن بعضها البعض، ومحاولة عدم الازدواجية فيما بينها بقدر الإمكان، بحيث يسهل ذلك على إدارة الكلية تحديد الخلل الصيادر من أين، ومن هو المسؤول عن ذلك. اعتماد وسيلة لتقويم الأداء تتضمن مشناركة كافة الأطراف (هيئة إدارية، هيئة أكاديمية، طلاب، مسؤولين، مراقبين)، ويتم في ضوئها معالجة مواطن الضعف، وتعزيز مواطن القوة. تبني نهج يمكن من مشاركة الأطراف المعنية بصنع القرارات، وذلك بتشكيل لجان ومجالس تشتمل على عدد من الأعضياء الممثلين لهم. تفعيل دور العنصر النسائي في إدارة الأقسام الرئيسية، وتمكينهن من القرب من الواقع الإداري، وذلك بتقليدهن بعض المناصب العليا.

المراجع:

أولاً: المراجع العربية:

1. الأكلبي، عايض بن إعربهافي (2019). العلاقة بين اليقظة الاستراتيجية وحوكمة الجامعات السعودية وفق مضامين رؤية المملكة العبية السعودية

2030: دراسة تطبيقية على جامعة شقراء. مجلة جامعة شقراء: جامعة شقراء، ع12 ، 1 - 36.

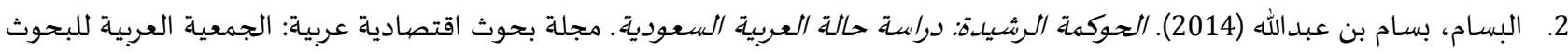

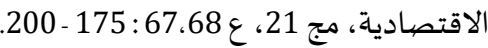
3. تعالبي، نوال علي (2015). الحوكمة البيئية العالمية: ودور الفواعل غير الدولدواتلية فيها. مركز الكتاب الأكاديمي.

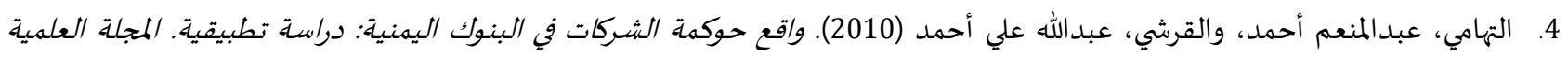

للبحوث والدراسات التجارية ، جامعة حلوان - كلية التجارة وإدارة الاعمال، ع3 ، 123 ـ 120 ـ 159.

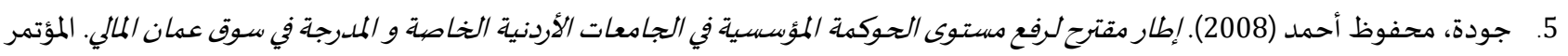
السنوي العام التاسع: الابداع والتجديد في الادارة: الادارة الرشيدة وتحديات الألفية الثالثة: المنظمة العربية للتنمية الإدارية، القاهرة: المنظمة العربية للتنمية الإدارية، 111 - 145.

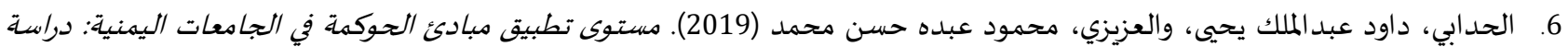

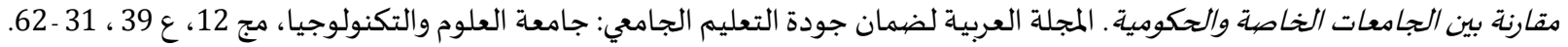

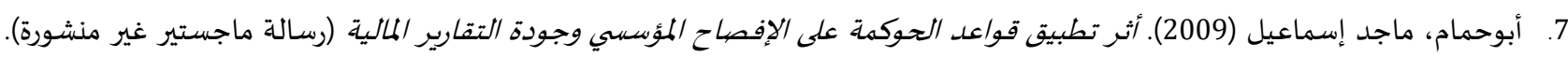
الجامعة الإسلامية بغزة، فلسطين. 8. الحميدي، منال حسين (2017). واقع تطبيق الحوكمة الرشيدة ومعوقاتها بجامعة الطائف من وجهة نظر أعضاء العباء الهيئة الأكاديمية. مجلة كلية

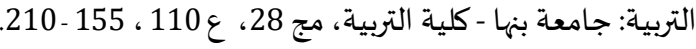

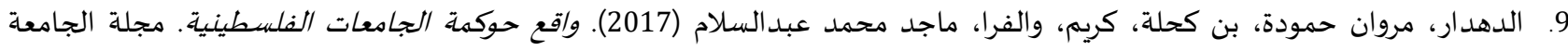

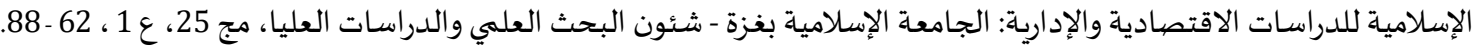

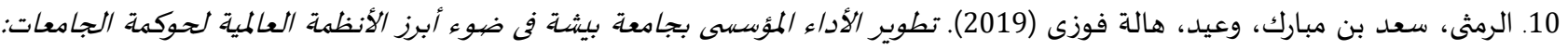

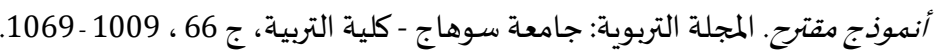

11. الزايدي، أحمد بن محمد (2019). واقع تطبيق مبادى الحوكمة بمكاتب التعليم بمحافظة جدة من وجهة نظر المشـفرين التويويين. مجلة جامعة

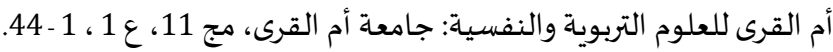
12. الزميتي، أحمد فاروق علي (2019). واقع تطبيق مبادئ الحوكمة بجامعة العريش: دراسة ميدانية . مجلة كلية التربية: جامعة بورسعيد - كلية

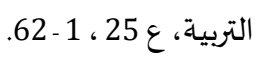
13. الزهراني، خديجة مقبول جمعان (2012). واقع تطبيق الحوكمة الرشيدة في الجامعات الأهلية السعودية وعلاقتها بالرضا الوظيفي والولاء

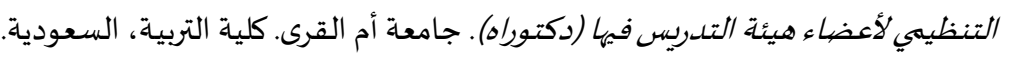

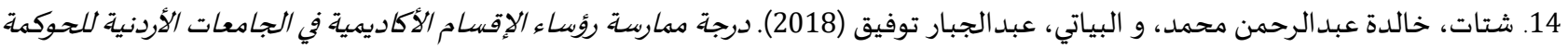
في العاصمة عمان من وجهة نظر أعضاء هيئة التدرليس. مجلة الزرقاء للبحوث والدراسات الإنسانية: جامعة الزرقاء - عمادة البحث العلمي، مج البهاء 260 - 245 ، 2 ، 18 
15. الشخشير ، آلاء محمود تيسير، و الفواعير، مؤيد عبد الرزاق (2015). الحسوكمة الجامعية وأثرها على الأداء المنظمى: دراسة تطبيقية فى الجامعات

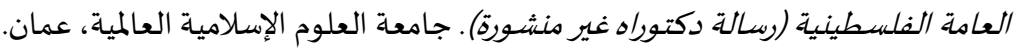

16. الشريف، عمر أحمد أبو هاشم، أسامة محمد عبدالعليم، هشام محمد بيومي (2013). الإدارة الإلكترونية: مدخل إلى الإدارة التعليمية الحسليثة. دار المنهاج.

17. الشمري، عادل بن عايد (2018). واقع حوكمة الجامعات السعودية ودورها في تحقيق رؤية المملكة 2030. مجلة العلوم التربوية: جامعة الملك

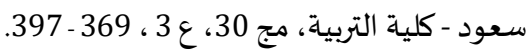

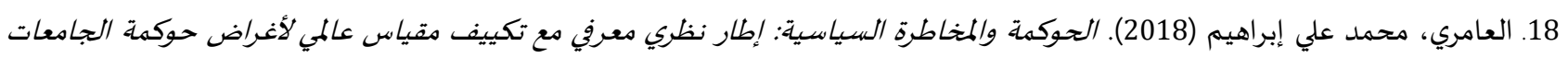

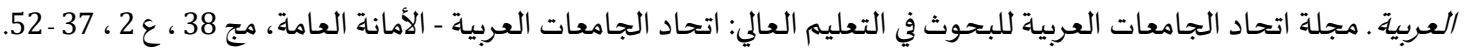
19. عبدالحكيم، فاروق جعفر (2011). حوكمة الجامعات: ملدخل لتطوير الإدارة من خلال الماد المشاركة. العلوم التربوية: جامعة القاهرة - كلية

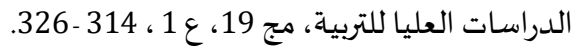

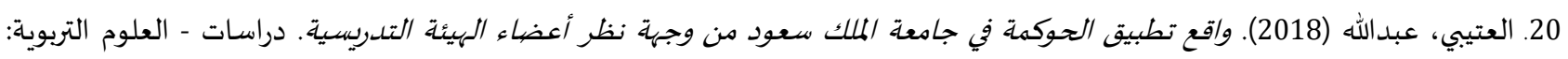
الجامعة الأردنية - عمادة البحث العلمي، مج 45، ملحق ،

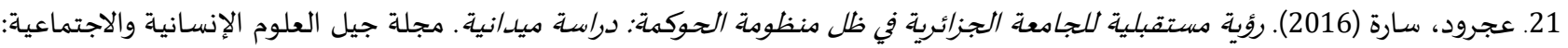
مركز جيل البحث العلمي، ع 26 ، 289 - 205. 22. العريني، منال بنت عبد العزيز بن علي (2014). واقع تطبيق الحوكمة من وجهة نظر أعضاء الهيئتين الإد/رية والأكاديمية العاملين في جامعة الإمام

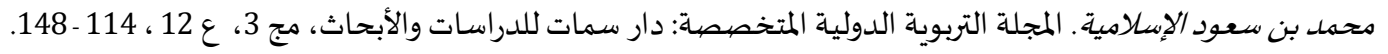
23. العساف، صالح (2016). الممدخل إلى البحث في العلوم السلوكية. الرياض. داضيه دار الزهراء.

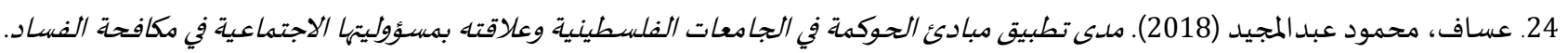
المجلة العربية لضمان جودة التعليم الجامعي: جامعة العلوم والتكنولوجيا، مج 11 ، ع 37 ، 3 ـ 30.

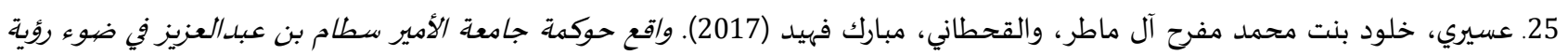
المملكة العربية السعودية 2030 من وجهة نظر القياد/ت الإد/رية والأكاديمية فيها. (رسالة ماجستير غير منشورة). جامعة الأمير سطام بن عبدالعزيز، الخرج. 26. غوانمة، فادي فؤاد محمد (2018). واقع تطبيق الحوكمة في الجادعات الأردنية الحكومية والتحديات التي تواجهها. مجلة جامعة القدس

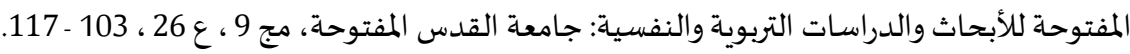
27. الفوزان، الجوهرة بنت سليمان (2017). إطار لتفعيل الحكوهة في الجامعات لتحقيق رؤية 2030. أبحاث مؤتمر: دور الجامعات السعودية في تفعيل رؤية 2030م: جامعة القصيم، القصيم: جامعة القصيم، 117 - 161 - 161. 28. محمد، حاكم محسن (2008). ضبوابط وآليات الحوكمة في المؤسسات الجامعية. المؤتمر العربي الثاني - الجامعات العربية تحديات وطموح: المنظمة العربية للتنمية الادارية - أعمال المؤتمرات، مراكش: المنظمة العربية للتنمية الإدارية، 320 - 326.

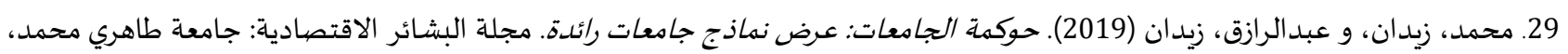

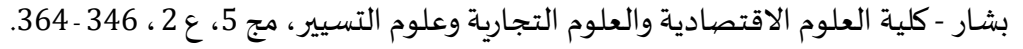

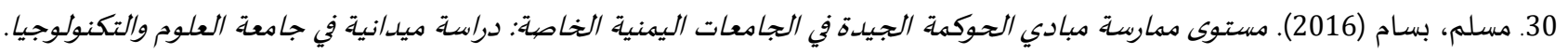
مجلة الدراسات الاجتماعياة: جامعة العلوم والتكنولوجيا، ع 49 ، 233 ـ 282.

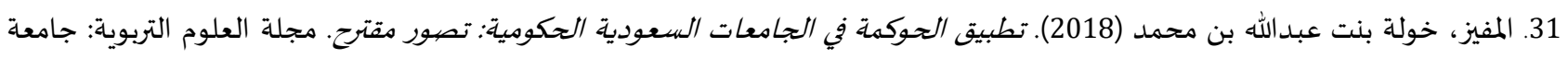

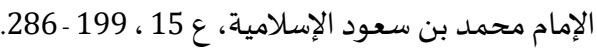

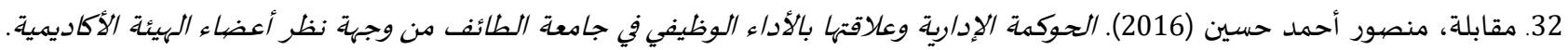

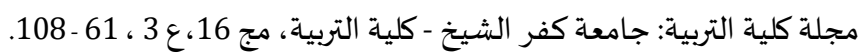

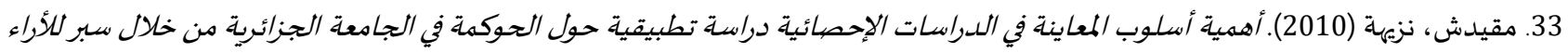
(رسالة ماجستير غير منشورة). جامعة فرحات عباس، الجزائر.

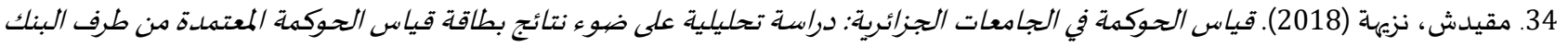

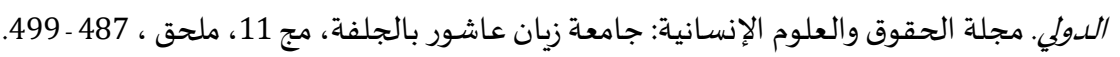


35. المنيع، نوره بنت منيع بن عبدالكريم، و الخنيزان، تهاني بنت محمد بن ناصر (2017). حوكمة الجامعات الحكومية لتحقيق رؤية المملكة العببية

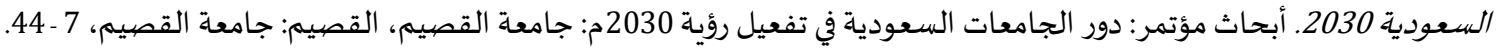

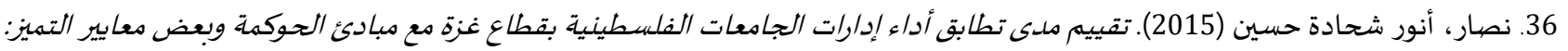

دراسة ميد/نية. مجلة البحث العلمي في التربية: جامعة عين شمس - كلية البنات للآداب والعلوم والتربية، ع 16، ج 5 ، 331 ـ 348 - 348.

37. أبو النصر ، مدحت محمد (2015). الحوكمة الرشيدة: فن إدارة المؤسسات عالية الجودةد. المجمموعة العربية للتدريب والنشر.

38. النوباني، خولة فريز، صديقي، عبد الله (2016). حوكمة المؤسسات المالية الإسلامية. كرسي سابك لدراسات الأوراق المالية الإسلامية. جامعاة

الإمام محمد بن سعود الإسلامية.

39. الورهي، أفنان بنت سعد بلن بن محممد، و الغامدي، علي بن مرزوق بن معيض. (2019). واقع تطبيق الحوكمة في وزارة التعليم بالمملكة العربية

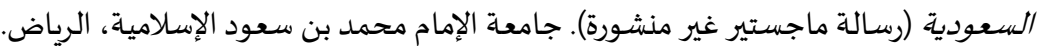

ثانياً: المراجع الأجنبية:

1. Hamada, H. (2019). Governance and Expertise in the Teaching Profession: An Analysis of Contemporary Japanese Educational Reforms. ECNU Review of Education, 2(2): 166-177.

2. Muhsin, S., Nurkhin, A., Pramusinto, H., Afsari, N., \& Arham, A. F. (2020). The Relationship of Good University Governance and Student Satisfaction. International Journal of Higher Education, 9(1), https://doi.org/10.5430/ijhe.v9n1p1.

3. Salahudin, S., Nurmandi, A., Fajar, M., Mutiarin, D., Siregar, B., Sulistyaningsih, T., ... \& Karinda, K. (2019). Developing Integrity University Governance Model in Indonesia. International Journal of Higher Education, 8(5): 185-199, https://doi.org/10.5430/ijhe.v8n5p185.

4. Salmi, J. (2019). Academic governance and leadership in Vietnam: Trends and challenges. Journal of International and Comparative Education, 8(2): 103-118, https://doi.org/10.14425/jice.2019.8.2.103.

5. Sayidah, N., Ady, S. U., Supriyati, J., Winedar, M., Mulyaningtyas, A., \& Assagaf, A. (2019). Quality and University Governan ce in Indonesia. International Journal of Higher Education, 8 (4): 10-17.

ثالثاً: المراجع الإلكترونية:

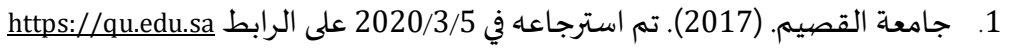
2. 


$$
\text { المجلة الدولية للدراسـات التربوية والنفسية }
$$

International Journal of Educational \& Psychological Studies (EPS)

\title{
The governance reality of college education at Qassim university in light of Kingdom vision 2030
}

\author{
Raghad Saleh Mohammed Al-rodhan \\ Faculty Education, Qassim University, KSA \\ raghad488@hotmail.com
}

\author{
Received : 18/4/2020 Revised : 29/4/2020 Accepted : 16/5/2020 DOI : https://doi.org/10.31559/EPS2021.9.2.18
}

Abstract: The study aimed to identify the level of governance of the Faculty of Education at Qassim university in light of the Kingdom's vision 2030 from the point of view of the faculty members, and to reveal whether there are differences between the responses of respondents due to the variables of the study (type, scientific rank), and try in to make possible proposals for its activation. Use the descriptive scanning method. The Asian Securities Council (CLSA) Global Standard, adapted by Amri (2018), was used to measure university governance as a data collection tool. It was applied to a simple random sample of 95 faculty members at Qassim University's Faculty of Education. The results of the study found that the level of activation of governance in the Faculty of Education at Qassim University came to a good degree and is lower than the highest, and that there are no differences between the answers of the sample due to the scientific rank, while there are differences in type and were in favor of males.

Keywords: Governance; Qassim University; Kingdom Vision 2030.

\section{References:}

1. Al'amry, Mhmd 'ly Ebrahym (2018). Alhwkmh Walmkhatrh Alsyasyh: Etar Nzry M'rfy M' Tkyyf Mqyas 'almy Laghrad Hwkmh Aljam'at Al'rbyh. Mjlt Athad Aljam'at Al'rbyh Llbhwth Fy Alt'lym Al'aly: Athad Aljam'at Al'rbyh - Alamanh Al'amh, $\operatorname{Mj} 38, ' 2,37-52$.

2. 'bdalhkym, Farwq J'efr (2011). Hwkmh Aljam'at: Mdkhl Lttwyr Aledarh Mn Khlal Almsharkh. Al'lwm Altrbwyh: Jam't Alqahrh - Klyt Aldrasat Al'lya Lltrbyh, Mj 19, ' 1 , 314 - 326.

3. 'jrwd, Sarh (2016). R'yh Mstqblyh Lljam'h Aljza'ryh Fy Zl Mnzwmh Alhwkmh: Drash Mydanyh. Mjlh Jyl Al'lwm Alensanyh Walajtma'yh: Mrkz Jyl Albhth Al'lmy, ' 26 , 289 - 305.

4. Al'ryny, Mnal Bnt 'bdal'zyz Bn 'ly (2014). Waq' Ttbyq Alhwkmh Mn Wjht Nzr A'da' Alhy'tyn Aledaryh Walakadymyh Al'amlyn Fy Jam't Alemam Mhmd Bn S'wd Aleslamyh. Almjlh Altrbwyh Aldwlyh Almtkhssh: Dar Smat Lldrasat Walabhath, Mj 3, ' $12,114-148$.

5. Al'saf, Salh (2016). Almdkhl Ela Albhth Fy Al'lwm Alslwkyh. Alryad. Dar Alzhra'.

6. 'saf, Mhmwd 'bdalmjyd (2018). Mda Ttbyq Mbad' Alhwkmh Fy Aljam'at Alflstynyh W'laqth Bms'wlytha Alajtma'yh Fy Mkafhh Alfsad. Almjlh Al'rbyh Ldman Jwdh Alt'lym Aljam'y: Jam't Al'lwm Waltknwlwjya, Mj 11, ' 37,3 - 30.

7. 'syry, Khlwd Bnt Mhmd Mfrh Al Matr, Walqhtany, Mbark Fhyd (2017). Waq' Hwkmh Jam't Alamyr Stam Bn 'bdal'zyz Fy Dw' R'yt Almmlkh Al'erbyh Als'wdyh 2030 Mn Wjht Nzr Alqyadat Aledaryh Walakadymyh Fyha. (Rsalt Majstyr Ghyr Mnshwrh). Jam't Alamyr Stam Bn 'bdal'zyz, Alkhrj.

8. Al'tyby, 'bdallh (2018). Waq' Ttbyq Alhwkmh Fy Jam't Almlk S'wd Mn Wjht Nzr A'da' Alhy'h Altdrysyh. Drasat - Al'lwm Altrbwyh: Aljam'h Alardnyh - 'madh Albhth Al'lmy, Mj 45, Mlhq, 673 - 687.

9. Alaklby, 'ayd Bn Shafy (2019). Al'laqh Byn Alyqzh Alastratyjyh Whwkmh Aljam'at Als'wdyh Wfq Mdamyn R'yt Almmlkh Al'rbyh Als'wdyh 2030: Drash Ttbyqyh 'la Jam't Shqra'. Mjlt Jam't Shqra': Jam't Shqra', '12, 1 - 36.

10. Abwhmam, Majd Esma'yl (2009). Athr Ttbyq Qwa'd Alhwkmh 'la Alefsah Alm'ssy Wjwdh Altqaryr Almalyh (Rsalt Majstyr Ghyr Mnshwrh). Aljam'h Aleslamyh Bghzh, Flstyn. 
11. Albsam, Bsam Bn 'bdallh (2014). Alhwkmh Alrshydh: Drast Halt Al'rbyh Als'wdyh. Mjlt Bhwth Aqtsadyh 'rbyh: Aljm'yh Al'rbyh Llbhwth Alaqtsadyh, Mj 21, ' 67,68: 175 - 200.

12. Aldhdar, Mrwan Hmwdh, Bn Khlh, Krym, Walfra, Majd Mhmd 'bdalslam (2017). Waq' Hwkmh Aljam'at Alflstynyh. Mjlt Aljam'h Aleslamyh Lldrasat Alaqtsadyh Waledaryh: Aljam'h Aleslamyh Bghzh - Sh'wn Albhth Al'lmy Waldrasat Al'lya, Mj $25, ' 1,62-88$.

13. Alfwzan, Aljwhrh Bnt Slyman (2017). Etar Ltf'yl Alhkwmh Fy Aljam'at Lthqyq R'eyh 2030. Abhath M'tmr: Dwr Aljam'at Als'wdyh Fy Tf'yl R'yt 2030m: Jam't Alqsym, Alqsym: Jam't Alqsym, 117 - 161.

14. Ghwanmh, Fady F'ad Mhmd (2018). Waq' Ttbyq Alhwkmh Fy Aljam'at Alardnyh Alhkwmyh Walthdyat Alty Twajhha. Mjlt Jam't Alqds Almftwhh Llabhath Waldrasat Altrbwyh Walnfsyh: Jam't Alqds Almftwhh, Mj 9, 'E 26, 103 - 117.

15. Alhdaby, Dawd 'bdalmlk Yhya, Wal'zyzy, Mhmwd 'bdh Hsn Mhmd (2019). Mstwa Ttbyq Mbad' Alhwkmh Fy Aljam'at Alymnyh: Drash Mqarnh Byn Aljam'at Alkhash Walhkwmyh. Almjlh Al'rbyh Ldman Jwdh Alt'lym Aljam'y: Jam't Al'lwm Waltknwlwjya, Mj 12, ' 39 , 31 - 62.

16. Alhmydy, Mnal Hsyn (2017). Waq' Ttbyq Alhwkmh Alrshydh Wm'wqatha Bjam't Alta'f Mn Wjht Nzr A'da' Alhy'h Alakadymyh. Mjlt Klyt Altrbyh: Jam't Bnha - Klyt Altrbyh, Mj 28, ' 110 , 155 - 210.

17. Jwdh, Mhfwz Ahmd (2008). Etar Mqtrh Lrf' Mstwa Alhwkmh Alm'ssyh Fy Aljam'at Alardnyh Alkhash W Almdrjh Fy Swq 'man Almaly. Alm'tmr Alsnwy Al'am Altas': Alabda' Waltjdyd Fy Aladarh: Aladarh Alrshydh Wthdyat Alalfyh Althalthh: Almnzmh Al'rbyh Lltnmyh Aledaryh, Alqahrh: Almnzmh Al'rbyh Lltnmyh Aledaryh, 111 - 145.

18. Almfyz, Khwlh Bnt 'bdallh Bn Mhmd (2018). Ttbyq Alhwkmh Fy Aljam'at Als'wdyh Alhkwmyh: Tswr Mqtrh. Mjlt Al'lwm Altrbwyh: Jam't Alemam Mhmd Bn S'wd Aleslamyh, ' 15, 199 - 286.

19. Mhmd, Hakm Mhsn (2008). Dwabt Walyat Alhwkmh Fy Alm'ssat Aljam'yh. Alm'tmr Al'rby Althany - Aljam'at Al'rbyh Thdyat Wtmwh: Almnzmh Al'rbyh Lltnmyh Aladaryh - A'mal Alm'tmrat, Mraksh: Almnzmh Al'rbyh Lltnmyh Aledaryh, 320 326.

20. Mhmd, Zydan, W 'bdalrazq, Zydan (2019). Hwkmh Aljam'at: 'rd Nmadj Jam'at Ra'edh. Mjlh Albsha'r Alaqtsadyh: Jam't Tahry Mhmd, Bshar - Klyt Al'lwm Alaqtsadyh Wal'lwm Altjaryh W'lwm Altsyyr, Mj 5, ' 2 , 346 - 364.

21. Almny'e, Nwrh Bnt Mny' Bn 'bdalkrym, W Alkhnyzan, Thany Bnt Mhmd Bn Nasr (2017). Hwkmh Aljam'at Alhkwmyh Lthqyq R'yt Almmlkh Al'rbyh Als'wdyh 2030. Abhath M'tmr: Dwr Aljam'at Als'wdyh Fy Tf'yl R'yt 2030m: Jam't Alqsym, Alqsym: Jam't Alqsym, 7 - 44.

22. Mqablh, Mnswr Ahmd Hsyn (2016). Alhwkmh Aledaryh W'laqtha Balada' Alwzyfy Fy Jam't Alta'f Mn Wjht Nzr A'da' Alhy'eh Alakadymyh. Mjlh Klyt Altrbyh: Jam't Kfr Alshykh - Klyt Altrbyh, Mj 16,'E 3 , 61 - 108.

23. Mqydsh, Nzyhh (2010). Ahmyh Aslwb Alm'eaynh Fy Aldrasat Alehsa'eyh Drash Ttbyqyh Hwl Alhwkmh Fy Aljam'eh Aljza'ryh Mn Khlal Sbr Llara' (Rsalt Majstyr Ghyr Mnshwrh). Jam't Frhat 'bas, Aljza'r.

24. Mqydsh, Nzyhh (2018). Qyas Alhwkmh Fy Aljam'at Aljza'ryh: Drash Thlylyh 'la Dw' Nta'j Btaqh Qyas Alhwkmh Alm'tmdh Mn Trf Albnk Aldwly. Mjlt Alhqwq Wal'lwm Alensanyh: Jam't Zyan 'ashwr Baljlfh, Mj 11, Mlhq, 487 - 499.

25. Mslm, Bsam (2016). Mstwa Mmarsh Mbady Alhwkmh Aljydh Fy Aljam'at Alymnyh Alkhash: Drash Mydanyh Fy Jam't Al'lwm Waltknwlwjya. Mjlt Aldrasat Alajtma'eyh: Jam't Al'lwm Waltknwlwjya, ' 49 , 233 - 282.

26. Nsar, Anwr Shhadh Hsyn (2015). Tqyym Mda Ttabq Ada' Edarat Aljam'at Alflstynyh Bqta' Ghzh M' Mbad' Alhwkmh Wb'd M'eayyr Altmyz: Drash Mydanyh. Mjlt Albhth Al'Imy Fy Altrbyh: Jam't 'yn Shms - Klyh Albnat Lladab Wal'lwm Waltrbyh, ' 16, J 5 , 331 - 348.

27. Abw Alnsr, Mdht Mhmd (2015). Alhwkmh Alrshydh: Fn Edart Alm'ssat 'alyh Aljwdh. Almjmw'h Al'rbyh Lltdryb Walnshr.

28. Alnwbany, Khwlh Fryz, Sdyqy, 'bd Allh (2016). Hwkmh Alm'ssat Almalyh Aleslamyh. Krsy Sabk Ldrasat Alawraq Almalyh Aleslamyh. Jam't Alemam Mhmd Bn S'wd Aleslamyh.

29. Alrmthy, S'd Bn Mbark, W'eD, Halh Fwzy (2019). Ttwer Alada' Alm'ssy Bjam't ByShh Fy Dw' Abrz Alanzmh Al'almyh LhwMh Aljam'at: Anmwdj Mqtrh. Almjlh Altrbwyh: Jam't Swhaj - Klyt Altrbyh, J 66 , 1009 - 1069.

30. Shtat, Khaldh 'bdalrhmn Mhmd, W Albyaty, 'bdaljbar Twfyq (2018). Drjt Mmarsh R'sa' Aleqsam Alakadymyh Fy Aljam'at Alardnyh Llhwkmh Fy Al'asmh 'man Mn Wjhh Nzr A'da' Hy't Altdrys. Mjlt Alzrqa' Llbhwth Waldrasat Alensanyh: Jam'eh Alzrqa' - 'madh Albhth Al'lmy, Mj 18, ' 2 , 245 - 260.

31. Alshkhshyr, Ala' Mhmwd Tysyr, W Alfwa'yr, M'eyd 'bdalrzaq (2015). Alhwkmh Aljam'yh Wathrha 'la Alada' Almnzma: Drash Ttbyqyh Fa Aljam'at Al'amh Alflstynyh (Rsalh Dktwrah Ghyr Mnshwrh). Jam't Al'lwm Aleslamyh Al'almyh, 'man.

32. Alshryf, 'mr Ahmd Abw Hashm, Asamh Mhmd 'bdal'lym, Hsham Mhmd Bywmy (2013). Aledarh Alelktrwnyh: Mdkhl Ela Aledarh Alt'lymyh Alhdythh. Dar Almnhaj.

33. Alshmry, 'adl Bn 'ayd (2018). Waq' Hwkmh Aljam'at Als'wdyh Wdwrha Fy Thqyq R'yt Almmlkh 2030. Mjlt Al'lwm Altrbwyh: Jam't Almlk S'wd - Klyt Altrbyh, Mj 30, ' 3 , 369 - 397.

34. T'ealby, Nwal 'ly (2015). Alhwkmh Alby'yh Al'almyh: Wdwr Alfwa'l Ghyr Aldwlatyh Fyha. Mrkz Alktab Alakadymy.

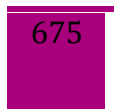

المجلة الدولية للدراسات التربوية والنفسية- المجلد9، العدد2- 2021، ص: 653-676 
35. Althamy, 'bdalmn'm Ahmd, Walqrshy, 'bdallh 'ly Ahmd (2010). Waq' Hwkmh Alshrkat Fy Albnwk Alymnyh: Drash Ttbyqyh. Almjlh Al'Imyh Llbhwth Waldrasat Altjaryh, Jam't Hlwan - Klyt Altjarh Wedarh Ala'mal, '3, 123 - 159.

36. Alwrhy, Afnan Bnt S'd Bn Mhmd, W Alghamdy, 'ly Bn Mrzwq Bn M'yd. (2019). Waq' Ttbyq Alhwkmh Fy Wzart Alt'lym Balmmlkh Al'rbyh Als'wdyh (Rsalt Majstyr Ghyr Mnshwrh). Jam'tAlemam Mhmd Bn S'wd Aleslamyh, Alryad.

37. Alzaydy, Ahmd Bn Mhmd (2019). Waq'e Ttbyq Mbada Alhwkmh Bmkatb Alt'lym Bmhafzh Jdh Mn Wjht Nzr Almshrfyn Altrbwyyn. Mjlt Jam't Am Alqra Ll'lwm Altrbwyh Walnfsyh: Jam't Am Alqra, Mj 11, ' 1 , 1 - 44.

38. Alzhrany, Khdyjh Mqbwl Jm'an (2012). Waq'e Ttbyq Alhwkmh Alrshydh Fy Aljam'at Alahlyh Als'wdyh W'laqtha Balrda Alwzyfy Walwla' Altnzymy La'da' Hy't Altdrys Fyha (Dktwrah). Jam't Am Alqra. Klyt Altrbyh, Als'wdyh.

39. Alzmyty, Ahmd Farwq 'ly (2019). Waq' Ttbyq Mbad' Alhwkmh Bjam't Al'rysh: Drash Mydanyh. Mjlt Klyt Altrbyh: Jam't Bwrs'yd - Klyt Altrbyh, ' 25, 1 - 62. 